Historic, Archive Document

Do not assume content reflects current scientific knowledge, policies, or practices. 


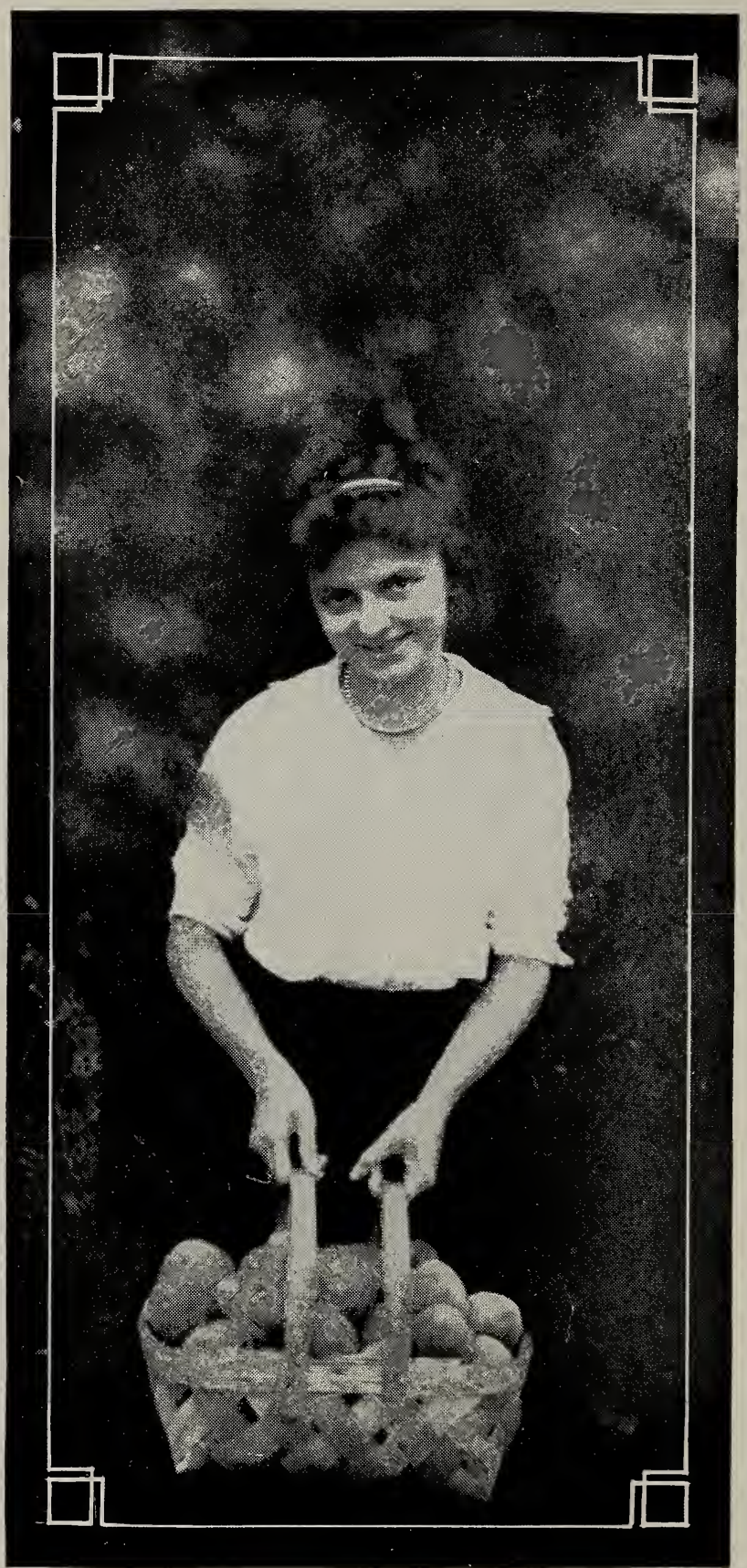

"Peaches"

A Basket of Stark Early Elbertas. 


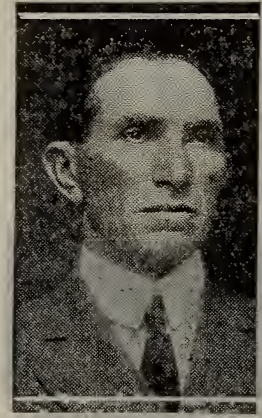

B. Carine

\section{A Peach Fortune}

Mr. Carine has made a fortune growing peaches -he has immense orchards containing 100,000 fruit trees, owns 4,000 acres of fruit lands and has the largest peach orchards in Connecticut.

His experience is remarkable only because it is the experience of one of the largest, most successful commercial peach growers of America-a man who landed in South Glastonbury 22 years ago with $\$ 22$ in his pocket and has amassed a fortune growing peaches. Mr. Carine's statement on Peach Possibilities is given below. He also has a signed article in reference to Stark Early Elberta on page 6 of this book.

\section{Profits in Peaches}

Peaches offer wonderful opportunities and the peach-growing field has barely been entered upon. Countless acres of land, which are now unused, should be planted to peaches, for the fruit will surely find a profitable market. Land that is not strong enough to produce ordinary farm crops will often support a peach orchard, and in many sections, land which cannot be used for any other purpose will grow magnificent fruit.

From the time of planting the trees to the marketing of the crop, a peach orchard demands less capital than any other kind of orchard, and it pays the quickest returns on the investment. One doesn't wait for years for his profits; the trees come into bearing young and are prolific; sometimes the second year, usually the third year and never later than the fourth year a profitable crop can be expected.

The wants of the peach tree are comparatively few-it will thrive on thin soils or on clay hillsides. Almost everywhere it is at home - nearly every corner of the United States, excepting a few extreme northern sections, will grown them profitably.

The home market orchard is the kind to plant to supply the ever insistent local market and city demand. Varieties should be selected that possess quality and are in demand for table use. They should always be sorts that will handle and keep reasonably well.

Next are commercial orchards - these command the advantages of large car-load shipments, big markets, etc. Fewer varieties are planted and while good quality is requisite, greater care should be exercised in selecting only those which will stand long shipment, keep well and ripen in sequence so as to put good peaches on the market from the earliest to the latest.

Lastly, the home orchard; a larger selection of the best varieties ripening from early summer until late fall; sorts that are good for table use or for canning or preserving. No home is complete without its own supply of peaches-peaches every day-they are so easy to grow and make such a big difference in the grocery bill.

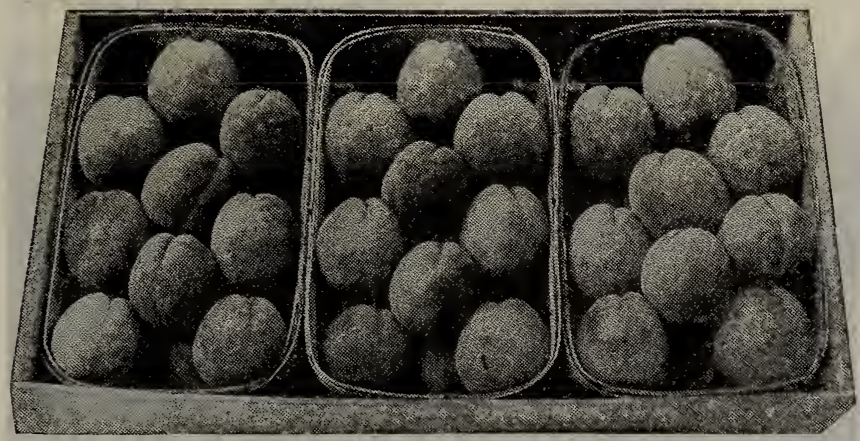

Stark Early Elberta - This crate of enormous beauties was shipped 2,000 miles, then kept a week before photographing. 


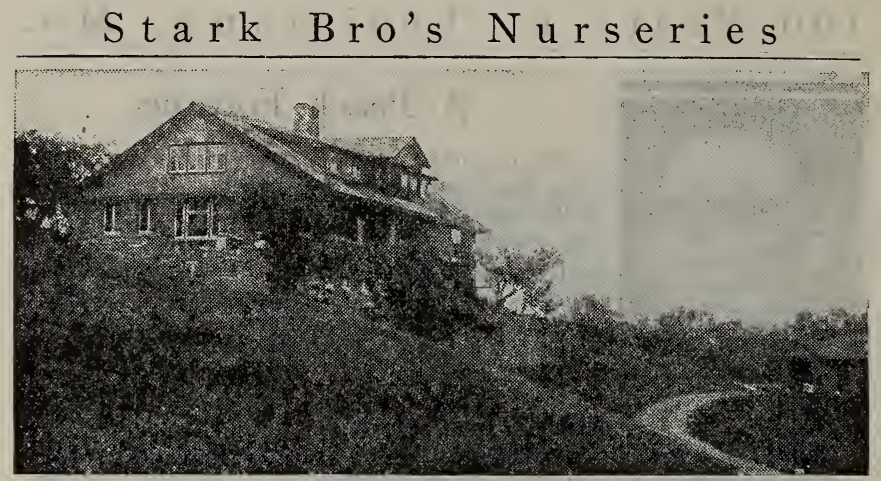

Country Home of B. Carine, Nestling in the Connecticut Hills among His Peach Orchard, which are the Largest in the State.

When a peach tree is properly trained, the expenses of picking are nominal, because it is naturally spreading in growth and with intelligent pruning, will develop a low, symmetrical head, all parts of which are easily accessible and can be picked from $t^{\dagger} \mathrm{e}$ ground. Compared with apples, the cost of marketing peachis is less; the heavy boxes and durable barrels used for apples are not required-a simple, lightly constructed crate is used. Sometimes baskets of good veneer are included and these will carry the fruit in perfect condition to distant markets.

In conclusion, let me state that improved varieties have been largely responsible for the present popularity of the peach growing industry. It should be the constant effort of the peach growing fraternity to discredit and weed out poor sorts and induce the planting of better ones. It should be the nurseryman's duty to advise and improve varieties, for it usually lies within the nurseryman's province when dealing with amateur planters, to suggest sorts that will either never pay their grower a dollar, or sorts that will be always in demand at good prices everywhere.

A good peach must possess many merits -it must ship well, be in demand on the markets, a sure cropper, hardy, prolific and a strong vigorous grower. Varieties that will not meet these requirements have no place in the peach orchard or in the nurseryman's catalog, for in the past, too many worthless varieties have been planted through error or poor judgment. Varieties like the old Sneed, Triumph, etc., which are either unattractive in appearance, watery, poor shippers, small, irregular size, or rot easily should never have been planted, and fortunately, they are being rapidly superseded by such sorts as Red Bird Cling, June Elberta, Alton, Greensboro, Stark Early Elberta, J. H. Hale, Krummel October and other peaches of merit.

I want to impress on inexperienced peach growers this fact: In the orchard, it costs no more to grow high quality, moneymaking sorts than the less valuable varieties of a generation ago. It is well to listen to men of experience-men who are willing to educate orchardists to appreciate and plant the better varieties which are taking well on the markets, are better peaches and insure greater profits.

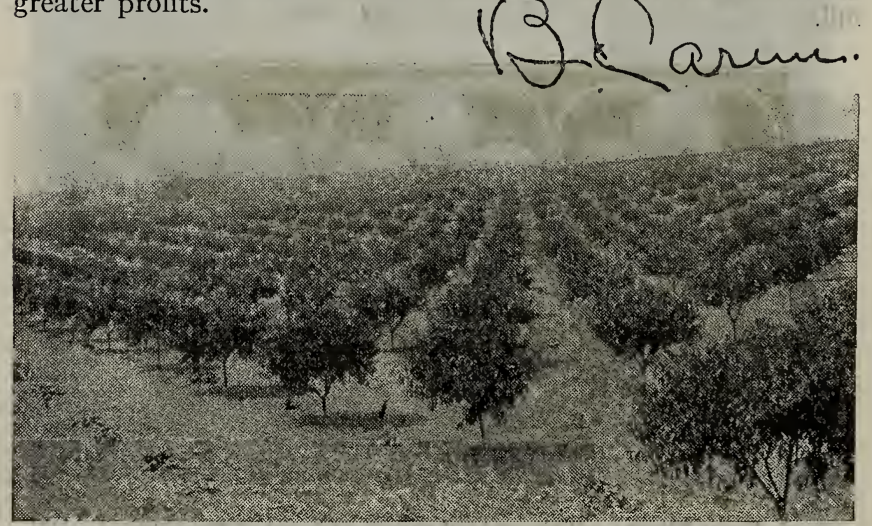

A Peach Orchard of 11,000 Trees Brought $\$ 30,000.00$ in One Season. Orchards of Stark Bro's Improved Varieties Pay Quick Returns. Note Inter-crops. 


\section{The World's Best Peach}

Stark Early Elberta. To describe this peach so you will appreciate its value is almost impossible. It must be seen and eaten and enjoyed to know anything about how beautiful and how good it is. The flesh is a rich yellow, with just a little red around the pit, and from the strong protecting skin clear through until the pit is reached it is sweet and luscious-none of the bitterness-none of the stringiness-none of the coarseness of the Elberta, but finegrained, melting meat with a tang and flavornever before found in a yellow peach.

Stark Early Elberta is to peaches what Stark Delicious is to apples. Dollars and cents regulate the value of a variety; a peach may be good in quality, handsome in appearance yet be valueless from a commercial standpoint because it is a poor shipper; it may be a good shipper and have the necessary quality, yet lacking in color and unattractive; it may have size and color, yet lacking in quality. To combine these good points in one peach has been the dream of nurserymen and peach orchardists for years. The old Elberta has size and color and ships well, but it is deficient in quality, and we have been trying for years to find a variety that had all the good points of Elberta and in addition have high quality.

With this object in view we grew and sent out millions of seedlings with the hope that one of these would bear the fruit we wanted. We even made a large cash offer to the man whose tree produced the peach we had in mind. One of these-the tree that became the original Stark Early Elberta. and that was destined to revolutionize peach growing, grew on the grounds of Dr. Sumner Gleason, of Kaysville, Utah. The owner, knowing of our hopes and desires, reported to us when he had thoroughly satisfied himself as to its value. Being a horticulturist of far seeing judgment he planted several orchards of the variety, and as these came into bearing and we saw that without a shadow of doubt we had found the peach for which we had so long been searching, we began its dissemination and introduction.

In introducing it we followed the plan that had made Stark Delicious famous. We included a Stark Early Elberta tree in thousands of orders shipped from our house, and within a few years these commenced to fruit all over the country and reports of its unapproached quality and gorgeous beauty began to come in. To-day we offer this great peach, thoroughly tested in nearly every state in the Union where peaches will stand, and absolutely proven the best yellow peach ever produced. As a money-maker no other peach grown has ever been in its class. It has every good point that a peach grower demands-size, beauty, quality, strong growing tree, hardiness, good shipper, and one of its strongest points is the fact that it ripens from 10 days to 2 weeks ahead of Elberta, coming on the market just exactly when peaches are scarce and prices are best.

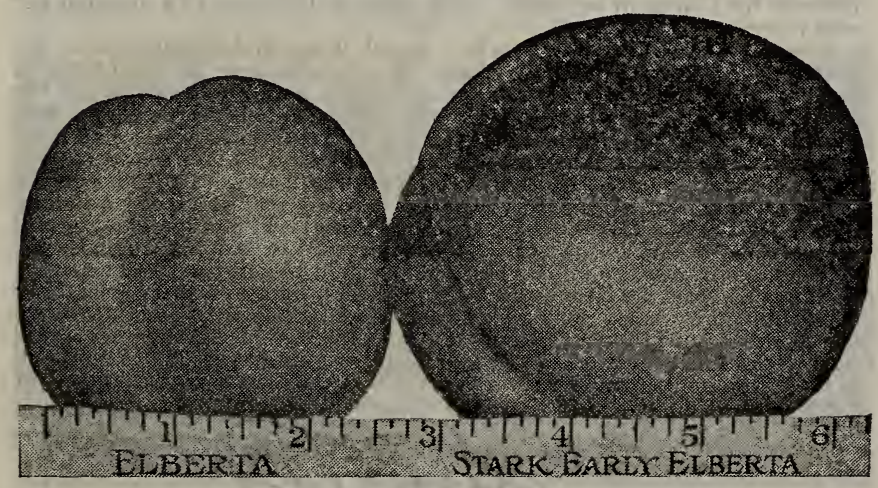

Average Specimens grown in the same orchard under identical conditions. Stark Early Elbertas brought $86 \%$ more than old Elberta same season. 
The strong, protecting skin and its solid flesh make it a wonderful shipper. It will carry from ocean to ocean and open up in good shape. The grower of Stark Early Elberta can ship to any market in the country where prices are best and know that his peaches will get there in good shape.

We do not advise entirely discontinuing the planting of Elberta, but Stark Early Elberta should be planted in connection with it by the tens of thousands. We firmly believe that this great peach will surely take the place of old Elberta in the orchard and on the market. Just as Stark Delicious and Stayman Winesap have practically stopped the planting of Ben Davis and apples of that class, so will the planting of Stark Early Elberta peach put the poor quality Elberta off the peach map.

The great mass of letters that are rolling in from peach orchardists who have it in bearing and who have seen it tell a peach story the like of which has never before been told, and while these letters differ in phraseology, they tell the same story and in practically the same way. They tell of its size, its beauty, its unapproached quality, the fact that it is a good shipper and ripens two weeks ahead of their Elbertas. Growers from all sections are planting them for they know what it means to be able to put these wonderful peaches on the markets within the next few years. A great peach growing opportunity is now offered, and while we are growing Stark Early Elberta by the hundreds of thousands, there is no question but what we could sell twice as many as we were able to produce this season. In fact, last season we turned down orders for thousands of trees that we could not supply.

The perfect peach is here. We say perfect because it has every good point and not a single fault.

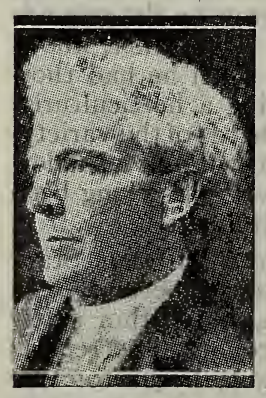

\section{Burbank Says Model Peach}

Stark Bro's,

Louisiana, Mo.

Gentlemen:

Stark Early Elberta is one of the handsomest, most shapely and beautifully colored of peaches and the quality fully carries out its appearance. I should judge it to be a model peach. Congratulations!

\section{Best Ever, Says State Horticulturist}

I have had an exceptionally good opportunity to observe Stark Early Elberta during the last four years; first, as we have a row of Stark Early EJbertas running through the middle of a three acre Standard Elberta peach orchard, and again we have been experimenting for the last three years in one of trie very first Stark Early Elberta peach orchards to be planted at Brigham City, the one belonging to Mr.: W. O. Knidson, therefore, you see I have had this peach under close observation for the last three or four years.

I consider this the very best commercial peach that has ever been introduced into the trade. Coming at a season preceding the Standard Elberta, by a week or ten days, often makes a difference of a hundred per cent increase in the returns.

As a heavy bearing peach it is fully equal, if not slightly superior, to the Standard Elberta. We have a chance to compare these in detail both on the aforementioned orchards under observation, and our records show the two varieties are practically equal in regard to its habit of bearing, in fact, the majority of trees of both sorts have to be thinned somewhat most seasons. The general appearance of the Stark Early Elberta as a market peach is superior to the Elberta and second to none. The deep yellow ground color, overlaid with a bright red cheek, makes an exceptionally showy fruit. We have kept Stark Early Elberta in storage alongside of the old Elberta and find practically no difference in keeping qualities.

The trees in our campus orchard were in full bloom last year when we experienced frost 26 degrees F., nevertheless, many of these trees have been thinned by hand during the past month. The trees also appear to be second to none in regard to vigor and hardiness. I consider the eating qualities of this peach to be superior to Elberta, in fact, second to no peach of its season and type. I have given my unqualified recommendation for the planting of this peach for commercial orchards.

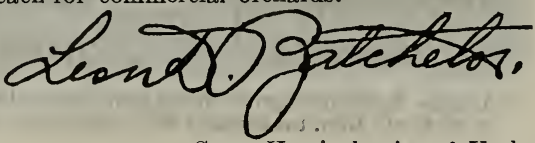




100 Years at Louisiana, Mo.

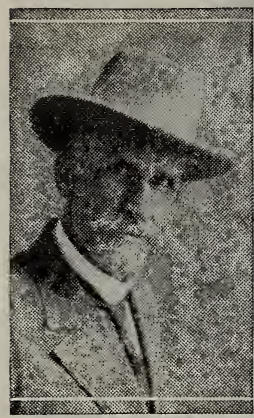

\section{Originator's Own Statement}

There is no question but what Stark Early Elberta is the most valuable sort yet introduced. It always sells at highest prices no matter how the market is; one fruit man told me that the only objection he had to the variety was that he could sell nothing else so long as he had Stark Early Elberta. Everyone notices their beautiful golden and red color, and when they find their quality is on an equal plane they are sure to ask for the same peach each season. Has fruited with me for twelve years and is the best yellow peach grown. It will prove valuable very far north as it is the hardiest sort known; the blossoms are of the large, pink, hardy type. There is no peach equal to it for canning, as it holds its peach flavor and shape remarkably well.

It has never failed to bear a crop here even when other peaches were quite badly injured by frost-in blossom and bud it is frost resistant, and the fruit is always large and uniform. Besides its attractiveness, it is sweet, rich, juicy, luscious-the highest quality of any yellow peach, yet the skin is strong and the flesh firm-making it a great shipper. In recent years I have sent shipments to all parts of the United States, from the Atlantic to the Pacific, and they arrived in perfect condition. This peach ripens a week to ten days a head of the old Elberta; and owing to its many superior points, it is rapidly replacing Elberta.

Mr. Christopherson, one of the foremost peach orchardists of Utah, says that if he plants an additional orchard of 10,000 trees, he will plant all Stark Early Elberta.

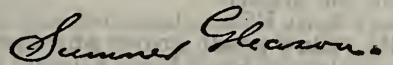

Originator, Davis Co., Utah.

\section{STARK BRO'S EXCLUSIVE CONTRACT FOR STARK EARLY ELBERTA}

In consideration of $\$$

the said sumner Gleason (the originator of Stark Early Elberta) does hereby grant, assign and set over unto Stark Bro's the exclusive right and control of all stock and buds of the original tree to the sole use and control of Stark Bro's; said Sumner Gleason agrees to personally supervise the cutting of buds from original bearing tree or any parent tree, and to prevent other nurserymen from obtaining buds from the original tree or off springs, and to protect Stark Bro's in the distribution and sale of Stark Early Elberta.

Stark Bro's N. \& O. Co., KAYSVILLE, UTAH, Feb. 16, 1914. Louisiana, Mo.

Dear Sirs-This is to inform you that I have never supplied buds from the original Early Elberta tree or other trees of the same variety to any nursery except Stark Bro's, Louisiana, Mo.

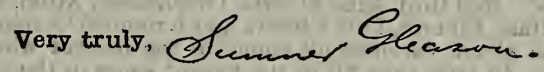

\section{Beware of Bogus Early Elberta}

We have been informed by our customers that bogus, so-called Early Elberta are being offered. On investigation it has been found that these are not the genuine Stark Early Elberta. They are entirely different and vastly inferior to the true Stark Early Elberta. Stark Bros. purchased from the originator the exclusive right of propagation (see above). Every genuine Stark Early Elberta tree bears a label with the autograph signature of the originator, Dr. Sumner Gleason.

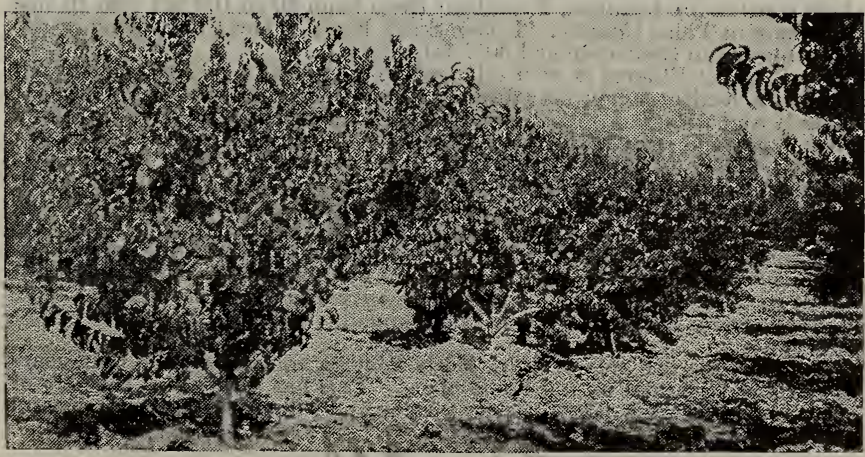

A Stark Early Elberta orchard - every tree loaded after $26^{\circ}$ of frost at blooming time. 


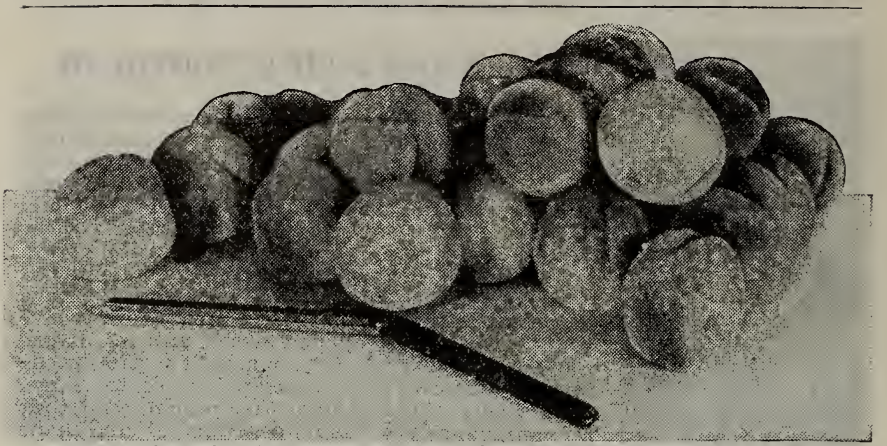

Four of these Stark Early Elbertas side by side covered a foot rule, and their quality was supreme.

\section{Largest Conn. Orchardist Says Greatest Peach}

"I would rather have an orchard of Stark Early Elberta than any other variety of peach. It brings me more money than anything else I grow. I have received at the rate of $\$ 2.70$ per crate when the old Erow. I have received at the rate of $\$ 2.70$ per

"Stark Early Elberta comes on the market about a week to ten days ahead of the old Elberta when the market is right, with no other peaches to spoil the market.

"Stark Early Elberta has a delicious sweet flavor. It is by far the best quality yellow peach grown anywhere extremely hardy, sure bearers.

"I am planting Stark Early Elbertas heavily. Four years ago I planted 700 trees, the next year 2000, last year 4000, and this year (spring 1914) I wanted 5000 or 6000 more but Stark Bros. were sold out and I got my order in too late to have it filled.

"I have stopped planting old Elbertas altogether and am going to stick to Stark Early Elbertas. I can't afford to grow Elberta when I know from experience that Stark Early Elberta is much more profitable.

"This peach shows up a good, strong, vigorous tree in the orchardis a heavy bearer and is a very fine shaped tree, spreading out more than any other variety; the blossoms are of the large pink hardy type.

"The Stark Early Elberta peach is much sweeter than any other yellow peach, with possibly one exception, and its quality is superior in every way.

"The fact that we were the first growers in this part of Connecticut to recognize the value of Stark Bros. new varieties of peaches and make a large planting has given us a distinct advantage over other growers. These new varieties always bring better prices than the old 'standard' sorts and they are also hardier and surer bearers.

"Of all the varieties I have grown I consider Stark Early Elberta, Alton, Krummel, Red Bird and June Elberta the most valuable-the biggest money-makers. We have planted and fruited these varieties by the thousands-in fact, our later plantings have been largely confined to these varieties and in future we shall plant almost entirely of these sorts.

"My experience has shown that our best succession of varieties is as follows: Red Bird, June Elberta, Greensboro, Alton, Stark Early Elberta, J. H. Hale, Elberta, Late Elberta and Krummel October.

"The above varieties all come on the market when good peaches are scarce. In fact, they fill in the vacant spots in the peach season and are better in all ways than other varieties which ripen at about the same time."

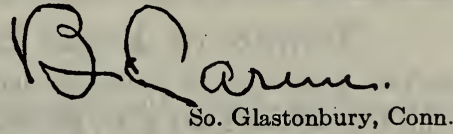

\section{Immense Size in the Southwest}

I received some western grown Stark Early Elberta this morning. While these peaches are beauties, I can beat them from 30 to 100 per cent in size right here in Tulsa County. I have Stark Early Elberta in bearing at my home place and they averaged $30 \%$ larger.

Stark Early Elberta is well adapted to this section. The tree is well spreading, healthy, vigorous grower, and makes in shape an ideal tree. It is hardy and withstands frost much better than old Elberta, bearing a crop when Elberta has failed. It ripens ahead of the old Elberta, in fact, in this locality, nearly all Stark Early Elberta are gone before old Elberta comes on the market, and its maturity comes at an opportune time in the peach market. The fruit is large, firm and colors highly before ripe, making it a desirable peach for shipping, and it seems to stand rough usage well. Its color, a rich yellow splotched with red, makes it a beautiful and attractive peach. It is a peach that "catches the eye" wherever displayed, and it fulfills in taste and quality all that its beauty and looks promise. I have planted several hundred of them commercially. It's the kind that brings the money.

You sent me one tree of Stark Early Elberta complimentary four years ago, which I planted on my home place. This has resulted in the sale of over a thousand trees of this variety for you and will mean another thousand this spring.

\section{Euradsameus.}




100 Years at Louisiana, Mo.

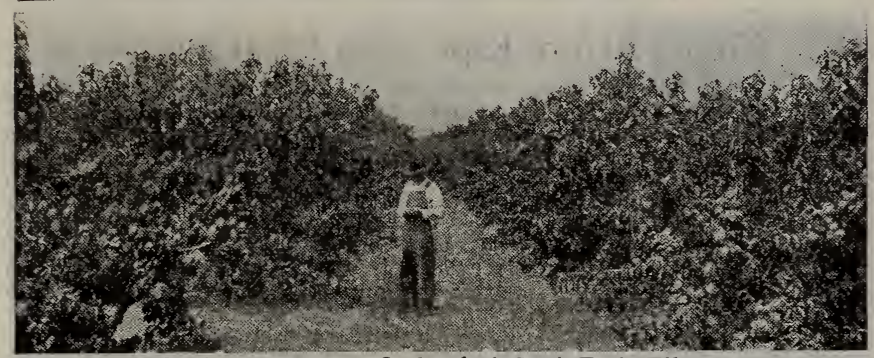

A fine investment-an Orchard of Stark Early Elbertas

\section{Hardiest, Surest Cropper}

I sent you some Stark Early Elberta peaches in August which will give you an idea as to the splendid record this variety is making in my orchard. These peaches weighed $3 / 4$ of a pound each. It was so dry in June and July that they did not grow as large as they did in 1913, when some of them weighed as much as 16 ounces each. I am sending you an affidavit made by some of the leading business men of my County, in which they state that Stark Early Elberta is the largest, most delicious peach ever seen.

The late frosts were very severe. All my plums except Omaha were killed and Stark Early Elberta had a full crop-the hardiest and surest cropper I have ever grown. I sold my Stark Early Elberta peaches at retail for 5 cents each. Everybody said that they were the largest and handsomest peaches they ever saw-yellow as gold and round as a balljust as perfect as nature could make them.

Stark Early Elberta bears a crop evenly distributed over the tree and they turn bright yellow and red long before they ripen. It is a splendid shipper; the flesh is very firm, although luscious and juicy; skin is strong and resists rot. Besides being the handsomest of peaches, it is the highest quality and richest peach I have ever grown. It ripens a week to ten days earlier than old Elberta and is larger than Elberta.

I have learned the lessons of horticulture. I am going to plant largely of Stark Early Elberta next spring because I know that it will make me more money than any other variety.

I know and feel that Stark Bros. have done more in fruit growing that feeds the millions than all other men on this continent. I know your history during the days of father, grandfather and great grandfather up to the present time. What you have done will go down on the pages of history to live as long as civilization will live.

$$
\text { Br. } 24 \text { Nersion }
$$

Orchardist and Experimenter, Fayette Co., Tenn.

\section{A Perfect Shipper-From Utah to Florida}

A crate of peaches all the way from Utah with hardly a flaw to be found on one of them! They are unwrapped and spread out, looking as if they were just picked from the tree. A funny thing about it is that the blush remains undisturbed and the red cheeks do not show anybody's handling. The size is just right, and the firmness of the flesh is remarkable. The value of a first rate yellow peach at this season can hardly be over estimated. I wish I lived in a peach country, and could plant an orchard (it would be pretty nearly all of it Stark Early Elberta) even if I am eightytwo years old. Think of it; eight days on the road-from Utah to Florida; and in as good shape as if picked yesterday.

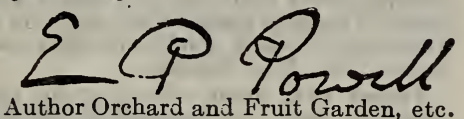

\section{Finest Peach in Existence}

As horticultural inspector I have had a chance to observe Stark Early Elberta in practically every orchard where it is grown in Box Elder County. The fact that this freestone yellow flesh peach can be landed on the market a week or ten days ahead of the standard Elberta makes it in my opinion the finest commercial peach in existence to-day.

The quality is all that could be desired, and it is a persistent, heavy and annual bearer. One of my neighbors produced on an average of two bushel boxes on his Stark Early Elberta trees in their fourth season. In fact, it is every bit as heavy a bearing variety as the original Elberta. In size and color it is superior to this great standard commercial peach. The deep rich yellow overlaid with red cheek makes the greatest show peach in my opinion that has ever been grown. In fact, the Stark Early Elberta peach has taken first premium at the Peach Day exhibit at Brigham City over all entries of the standard Elberta every year it has been shown. Last season there was one box of the Stark Early Elberta to about 50 boxes of the standard. Yet this one box was sufficient to take away the first prize in the freestone yellow flesh peach class. I have given my unqualified recommendation during the past season to all inquiries to plant Stark Early Elberta peach for commercial orchards.

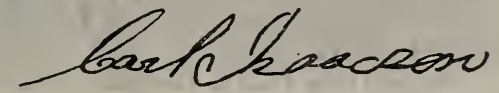

Horticultural Inspector, Box Elder Co., Utah. 


\section{Colors Before Ripe-An Ideal Shipper}

Stark Early Elberta surpasses any yellow peach on the market. It has beautiful yellow flesh, firm, juicy and rich. It does one's eyes good to see this peach, colored a beautiful yellow and red, ready for shipment long before it is soft enough to eat. Being firm, yet beautifully colored makes this peach ideal for long distance shipments. The old Elberta when picked with the same firmness for long distance shipments has to be picked almost green and when packed lacks the tints of the Stark Early Elberta, which appeal to the prospective buyer.

The flavor of the Stark Early Elberta is all that is to be desired and the flesh is smooth and almost melts in one's mouth. It ripens ten days to two weeks earlier than the Elberta and as a keeper has no superior.

I wish I could have prospective planters of peach trees with me in my orchard of twenty-five acres for just ten minutes that they might see this beautiful peach on thrifty vigorous trees, and I think they would plant the Stark Early Elberta peach-the best yellow peach on the market.
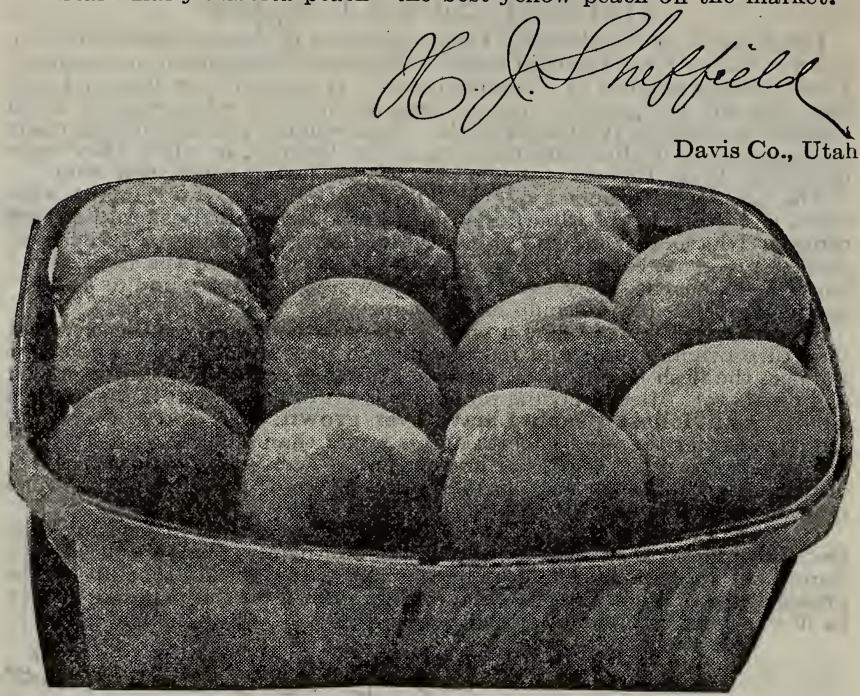

Stark Early Elberta — ideal Shipping Peach — Huge Size, Best Flavor.

\section{What Other Leading Peach Men Think of Stark Early Elberta}

Just What Is Needed. - Stark Early Elberta arrived from Utah in splendid eating condition. The skin indicates that the peach is going to be an A No. 1 shipper. The color is also very attractive; the blush being beautiful. The flesh for a long shipping peach is remarkably fine. It seems to be melting and very juicy, and the flavor is exceedingly good. I believe you are to be congratulated on having such a solendid peach. It seems to fit into our market requirements splendidly, coming into bearing earlier than regular Elberta, and having superior eating qualities and still being a splendid shipper. It seems to be just along the lines of what we need for a good commercial peach.-C. I. Lewis, Prof. of Horticulture, Ore. Exp. Station.

Finest Ever Seen.--Stark Early Elberta is by far the finest peach I have ever seen. As an orchard tree is is unequalled; a strong, vigorous grower, spreading, hardy in blossom and bud, a young bearer and a sure cropper. The fruit is creating a sensation on all markets, being large, beautifully colored, rich in appearance, juicy and altogether delicious. Coming on the market as it does ahead of old Elberta, it commands top prices, selling this season for $\mathbf{8 7 \%}$ more than old Elberta. No peach equals it for canning, as it holds its peach flavor remarkably well.

A splendid keeper, excellent shipper, and for profit it excels all others. Stark Early Elberta should be included in every order for peach trees; in fact, the majority of plantings should be of this excellent sort.-A. G. Butcher, Davis Co., Utah.

Noted Editor Endorses It.-When I was with the Utah Agricultural College I visited the orchard of Dr. Gleason in which Stark Early Elbertas were growing alongside of Elberta. It made a very favorable impression on me at that time not only on account of its earliness, but from the superior quality of its fruit as compared to Elberta and I have watched it with a great deal of interest. It certainly is a dandy peach, - E. H. Favor, Editor Fruit Grower and Farmer, St. Joseph, Mo.

Big, Brilliant Beauties.-The crate of Stark Early Elberta peaches received yesterday. As I removed the big, brilliant beauties from the box, I realized why it is that the peach growers of the whole country are so enthusiastic over this peach. The fruit, every one of them, was in perfect condition.-Thos. F. Rigg, Iowa Falls, Iowa, Horticultural Experimental Grounds.

(Shipped from Utah to Louisiana, Mo., and then reshipped to Iowa Falls, Iowa, arrived in perfect condition.--Stark Bros.) 


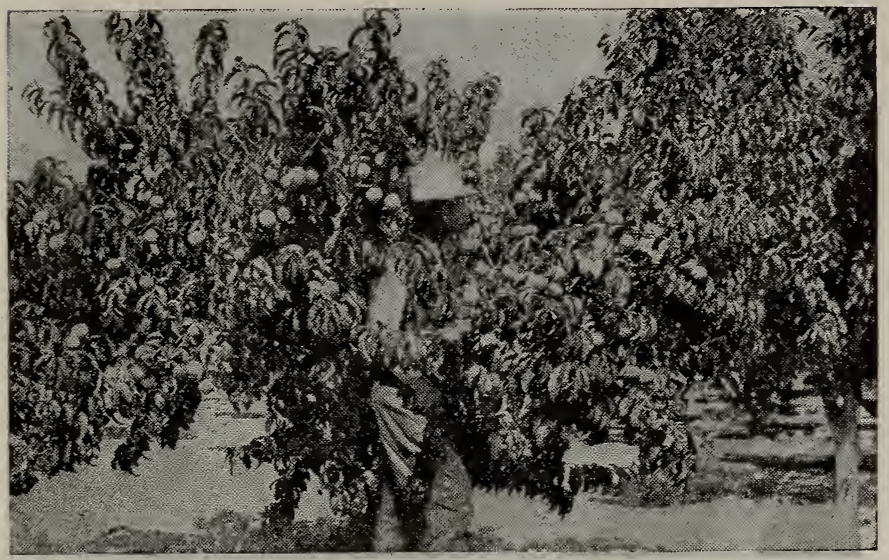

A loaded Stark Early Elberta-the great quality market peach.

Will Supplant Elberta.-Stark Early Elberta peach is exceptionally fine in size, color and exquisite in quality. Doubtless this remarkable peach will succeed in supplanting the original Elberta as a first-class commercial sort. Its appearance quickly commends it to the trade.-T. C. Foster, State Orchard Demonstrator, Union Co., Pa.

An Excellent Shipper.-The Stark Early Elberta peaches received seven days from the time they were mailed and in good condition. This certainly shows that it is an excellent shipping variety and the size and color will give it high rank for market purposes. In texture and flavor it has few equals and if it possesses the required hardiness and productiveness it should be given a prominent place among commercial varieties.-L. R. Taft, State Inspector of Nurseries and Orchards, East Lansing, Mich.

(Dr. Gleason, the originator, says is is the hardiest of all peaches. Reports from orchardists who have them in bearing in Iowa, Oklahoma, Kansas, Utah, Washington, Missouri, Illinois, Connecticut, Tennessee and other states, also the action of the trees on our own grounds bear out Dr. Gleason's statement. Ten years of close observation of the tree in the orchard enables us to make the positive statement that it ranks with the very hardiest varieties. As to its bearing qualities, scores of growers from many states tell of the great crop it produces. It often surpasses old Elberta in this respect. - Stark Bros.)

Fills a Long Felt Want.-A very good peach indeed; resembles Elberta very much in appearance, but it is more handsome, freer from fuzz and of better quality. If it has the other good qualities of Elberta it should fill a long felt want coming at the season that it does.-W. Paddock, Prof. of Horticulture, Ohio State University.

Far Hardier Than Elberta.-This year as before, it did not seem to care even a bit for low temperature, which held on far longer than normal on Long Island, while old Elberta played the usual trick with the neighbors and produced nothing. It certainly is a corker in color and looks.-H. B. Fullerton, Director Long Island Exp. Sta.

Editor "Better Fruit" Says a Winner.-Stark Early Elberta is far superior in flavor, richness, sweetness and juiciness to regular Elbertas. While old Elberta has proved a good peach it is decidedly lacking in the qualities which go to make up for quality. I certainly believe this peach of yours is a winner.-E. H. Shepard, Editor "Better Fruit," Hood River, Oregon.

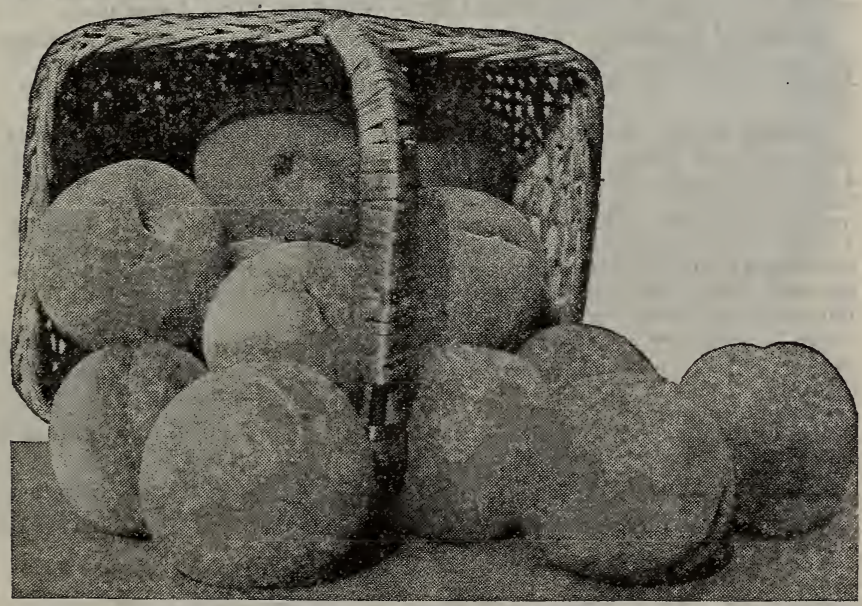

They look like a basket of golden cannon balls-perfect Stark Early Elbertas. 


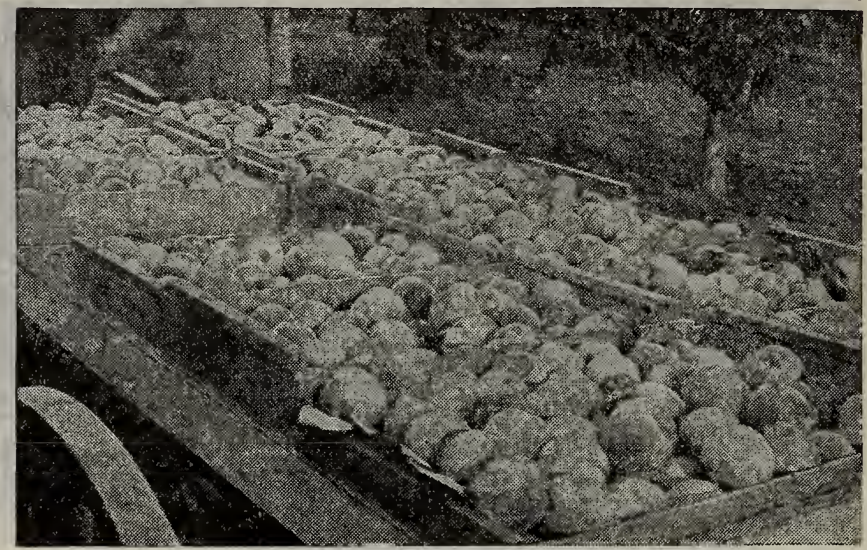

Stark Early Elbertas-a wagon load fresh from the trees going to the grading sheds-old Elbertas still green.

More Than We Claim for It.-Stark Early Elberta with no artificial watering and but little attention has made wonderful growth, therefore, we consider it almost phenomenal that they are living, much less, producing fine fruit this year. We believe this peach is all and probably a bit more than you claim for it.-John S. Cox, Tom Green Co., Tex.

Will Bring $100 \%$ More Than Flberta.-I believe this is the peach we have been waiting for for many years. The fact that it reaches the market from a week to ten days ahead of the original Elberta will often make a difference of one hundred per cent increase on the market price. In fact, it strikes the market at just the time when yellow freestone peaches are at a premium. There is no peach of this type which compares with it for quality. From a commercial point of view its habit of early, heavy bearing makes it all that could be desired and trees are vigorous and hardy. Compared with the standard Elberta I certainly believe the Stark Early Elberta is superior in every way, and would give considerable to have onehalf of my whole orchard of this variety, rather than of the original Elberta. -N. F. Hansen, Logan, Utah.

Season of Ripening of Special Value.-Yours of the 2nd, together with one of the Early Elberta peaches, has been referred to me on my return to the office today. Fruit is very fine, indeed, and it also apparently keeps well, judging from the present specimen which has been held in storage eleven days. If the tree and bearing qualities are up to the standard of the regular Elberta, it is undoubtedly a very valuable addition to our varieties of peaches. Its season of ripening is of special value.-J. P. Stewart, Experimental Pomologist, Pa. State College.

Color Superior to Elberta.-I am gratified to observe that Stark Early Elberta impresses me as representing one of the finest varieties of peaches I have ever sampled. The rich yellow color and red blush is equal in color if not superior to Elberta. I regard the flavor as superior to the Elberta. At the same time the peach seemed equally firm, having equally tough skin and apparently the keeping and shipping qualities of the Elberta.J. C. Whitten, Dean of Horticulture, Mo. State University.

Beautiful, Big and Delightful, and coming at such a time as it does it certainly is a good peach to have, or rather not to have after you have grown it, because I believe it would be better to have the extra dollars it will bring.-J. Horace McFarland, Pres. American Civic Association.

Queen of Peaches.-As Stark Delicious is readily recognized as King among apples, Stark Early Elberta should be crowned Queen of peaches.James Handly, Sec. Mississippi Valley Apple Growers' Ass'n., Adams Co., Ill.

Adding to the Wealth of the World.-I am surprised and delighted with the Stark Early Elberta. It is the most beautiful and perfect peach I have ever seen. On close examination I find its texture much finer than that of Elberta. Its color is also much richer and more beautiful, both inside and outside. This is a great acquisition to the wealth of the world. You are to be congratulated on the discovery of this fine veach-you are meriting all honor for your enterprise. I am sure I have never seen the equal of this peach, especially when we consider its ripening season.-E.W. Kirkpatrick, noted Texas peach authority.

Later, 1914-The Most Perfect Peach in Captivity.-The size, color, shape, texture, quality and beauty is the acme of desire. The rapid speed in improvement of varieties of fruit is fascinating and amazing. In the midst of this unparalleled advance of modern science and discovery in every domain of human activity, we find horticulture not lagging.-E. W. Kirkpatrick, Texas.

Finest on the Market.-My Stark Early Elberta had a fine crop last year. Commission men said they were the best they had seen on the market.-C. C. Pickering, Fairfield Co., Ohio.

None Can Touch It.-Stark Early Elberta is in every way superior to old Elberta. I planted 100 trees from your nurseries which bore the second year. As a shipper and keeper, none other can touch it.-L. A. Smith, Placer Co., Calif. 
Thirteen Inches in Circumference.-I send you photograph of Stark Early Elberta measuring 13 inches in circumference and weighing 12 ounces-a product of a dry season.-Joe Colford, Cochise Co., Arizona.

No Injury From Late Frosts.-My Stark Early Elbertas are the best early peach I have. More fruit this year than any other variety. Late frost killed a good portion of my crop, but Stark Early Elbertas have good crop.-J. N. Hildreth, Pawnee Co., Okla.

Absolutely the Best.-Have tested Stark Early Elberta and find it by all odds the best peach of its class - far superior to Elberta. It is absolutely the best for these Northwestern States.-M. F. Perry, Yakima Co., Wash.

Finest Ever Seen.-My Stark Early Elberta peach trees last summer bore the finest peaches I have ever seen.-C. H. Wilkinson, Berrien Co., Mich.

Conservative Estimate of a Noted Authority.-While in Utah I had the pleasure of visiting the Stark Early Elberta peach orchard of MIr. Knudson and eating the fruit directly from the tree. This fruit is of very attractive appearance, being very large and beautiful color. The flesh is firm, yet very juicy; of good texture for canning and for shipping; of attractive yellow color; moderately sweet, yet with a resfreshing mild acidity, good flavor and good quality. It has a very deep red stain of the flesh at the pit. On the whole, it seems to be a variety of great merit.-Prof. S. A. Beach, Iowa State College, Dept. of Horticulture.

Have Cut Out Elbertas. - All fruit men visiting this section make it a point to see the Stark Early Elberta orchards. We have cut out old Elberta entirely, as we know that Early Elberta possesses all the qualities of old Elberta and then some.-E. M. Tyson, Boxelder Co., Utah.

Superior to All.-My Stark Early Elberta bore two years after planting. They are of finest quality, very large and beautifuI. I believe the most profitable and superior in every way to all peaches the orchardist can plant. -O. J. Taylor, M. D., Sedgwick Co., Kansas.

Big as a Pint Cup.- Stark Early Elberta in my orchard were larger than a pint cup and nearly 20 days earlier than old Elberta. Could not supply the demand.-S. W. Gray, Pendleton Co., Ky.

A Crop Every Year.-Stark Early Elberta is at least a week ahead of old Elberta in ripening - a heavy bearer of beautiful yellow fruit; good shipper and superior in quality to old Elberta. You are assured of a crop every year. I would advise any one putting out a peach orchard to plant this peach liberally.-F. Dando, Chelan Co., Wash.

Of Incalculable Value.-Stark Early Elberta peach impresses me greatly. As grown here, it is many points superior to Elberta. Its beauty fine grained meat, wonderful keeping quality, combined with the fact that it comes at a time when we can get the highest market price, makes its value to us incalculable.-R. M. Love, Eddy Co., N. M.

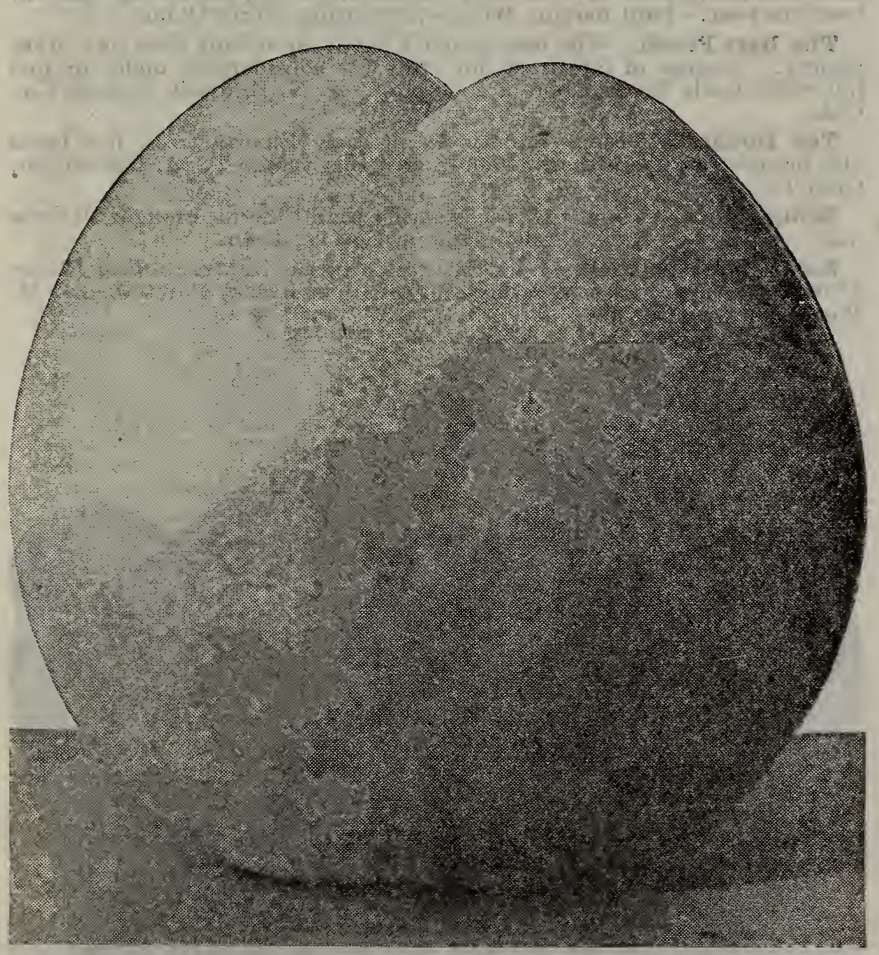

World's Greatest Peach-Stark Early Elberta. Perfect Freestone. Glorious Golden Red-blushed Beauties.-Catch the Eye and Enrapture the Tongue. 
Of Highest Rank. - Stark Early Elberta should be classed as the Grimes Golden of the peach family. - Silas Wilson, Canyon Co., Idaho.

Higher Praise Impossible.-The only trouble with the Stark Early Elberta peaches is that they are too good to be eaten in small lots. Even my hay fever fades into comparative insignificance when I think of the Stark Early Elberta.-Adv. Mgr. Farm Journal, Philadelphia.

Free From $\mathbf{F u z z}$. The entire freedom from the stone itself, and more particularly from the flavor of the stone, makes this a very desirable peach. It furthermore has the good qualities of attractive color, rough skin, freedom from fuzz and firm meat.-S. J. Hunter, Kansas State Entomologist.

Would Plant Nothing Else.-Stark Early Elberta is a perfect freestone, hardy in bloom and will not freeze as quickly as common Elberta. I would not plant anything else.-N.S. Christoffersen, Boxelder Co., Utah.

Extremely Hardy. - Stark Early Elberta is the best peach on low ground ever seen in this part of the country. Will stand where Elberta is killed. -Louis Seibert, Taney Co., Mo.

Eight Days Earlier.-Beautiful on the outside and delicious on the inside. Ripens about eight days before Elberta.-P. B. Doby, Clark Co. Ark.

Finest Peach.-Ripens about ten days ahead of Elberta; the finest peach I ever tasted.-J. F. Anderson, Tuolumne Co., Calif.

At Koshkonong.-Stark Early Elberta peach with us are prolific bearers and have set an enormous crop this year. In fact, they are a little overloaded.-Koshkonong-Brandsville Fruit Shippers' Association.

By Far the Best.- Planted 51 peach trees from you Spring 1908. Stark Early Elberta is by far the best in quality of the lot. - Selby Postiethwait, Belmont Co., Ohio.

An Editorial Opinion.-Stark Early Elberta is better than the original in quality, size and beauty and it keeps much better. I have no hesitancy in saying that I have never seen a better yellow peach. - C. W. Burkett, Editor "American Agriculturist."

Always Brings Top Prices.-Stark Early Elberta is a very fine peach, ripening here from a week to ten days earlier than old Elberta. Those who had Stark Early Elberta last season made more on them than the Late or Elberta Queen, as the market was over-stocked with the latter.-F. Dando, Pleasant Valley Fruit Orchard, Chelan Co., Wash.

More Attractive Than Elberta.-Stark Early Elberta were ready to ship long before the common Elberta and were more yellow and more attractive.-F. S. Carman, Wayside Orchard, Mesa Co., Colo.

Most Highly Flavored. - Stark Early Elberta is the finest, most highly flavored peach I know. I find a ready sale for all of my fruit; can't supply the local demand.-S. B. Irvine, Pike Co., Mo.

Fruiting in the Orient.- In spite of shipment being delayed on road, the Stark Early Elberta trees survived and blossomed this spring and will bear this year.-Paul Bergun, Weihsien Shanting, North China.

The Best Peach. - The best peach I have; more fruit than any other variety. Because of late frost our crop was considerably under norma but Stark Early Elberta bore a good crop.-J. N. Hildreth, Pawnee Co. Okla.

Ten Dollars a Tree.-Twenty Stark Early Elberta trees, five years old, brought me more than $\$ 10.00$ a tree this year.-T. M. Boatwright, Otero Co., N. M.

Brings More.-About two weeks earlier than Elberta; brought 50 cents more per bushel.-A. N. Nesbitt, Humphreys Co., Tenn.

Six Dollars a Bushel.-Stark Early Elberta sold in Mt. Sterling, Ill., for $\$ 3.00$ ner bushel, and sold as high as $\$ 6.00$ per bushel at retail. $-R$. M. Barnett, Brown Co., Ill.

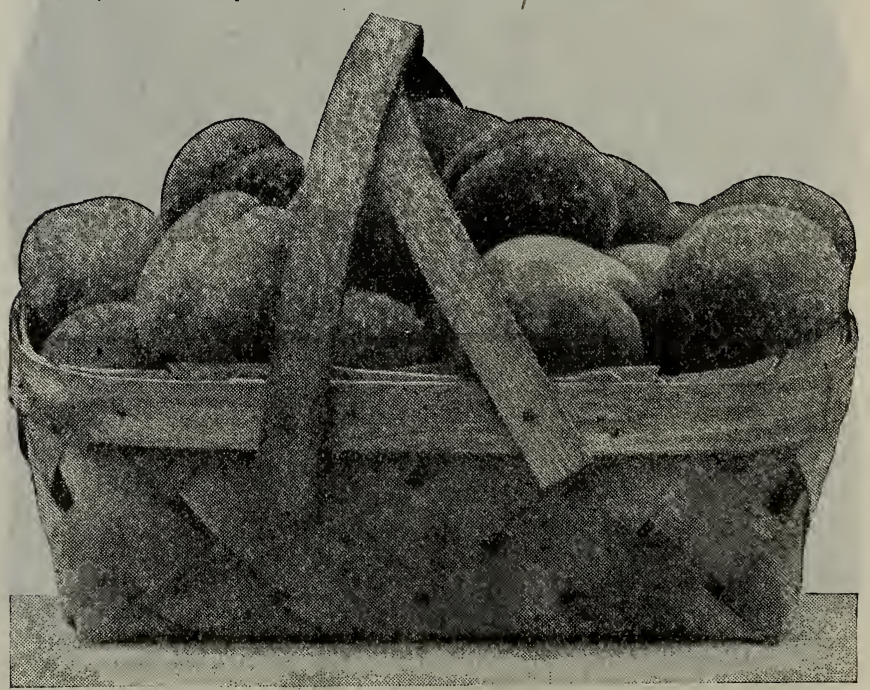

King of Peaches-Stark Early Elberta-will revolutionize peach growing. 


100 Years at Louisiana, Mo.

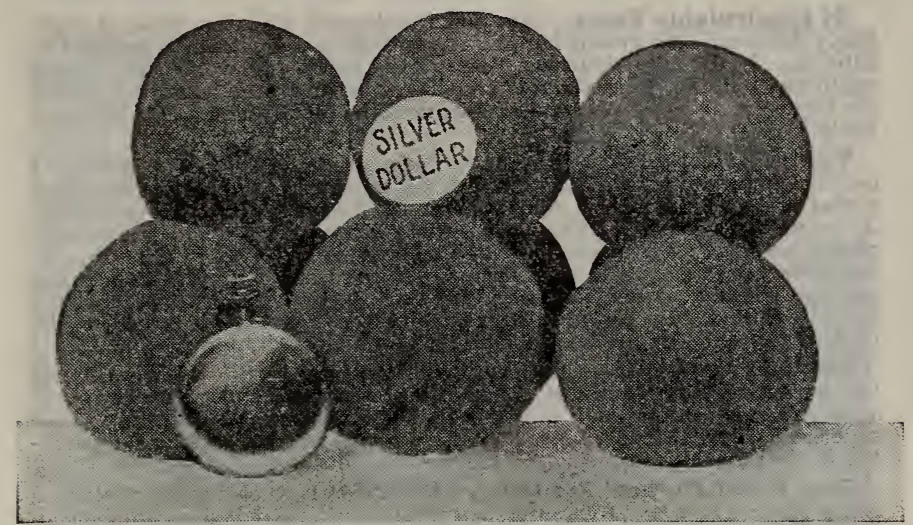

The Biggest Peaches Ever Received by Stark Bros-these Enormous Stark Early Elbertas A veraged 1.5 Ounces-Grown in Tennessee-Incomparable Quality.

Finest They Ever Tasted.-Our Stark Early Elberta tree bore this year. We picked them on August 20th and on September 13th we picked the old Elberta, standing side by side and the trees the same age. We pronounced the specimens of Stark Early Elberta the finest quality of any peach we had ever tasted.-J. W. Bell \& Son, Chautauqua Co., N. Y.

In New England. - From my Early Elberta I picked three baskets, while late Crawford will hardly make a basket. I am more than pleased with Early Elberta; they were the handsomest peaches here this year.E. W. Newbury, New London Co., Conn.

Finest He Ever Saw or Tasted.-Stark Early Elberta peach was loaded with the finest peaches I ever saw or tasted; that is the reason why I am planting more.-J.F. Anderson, Tuolumne Co., Calif.

The Best Variety.-Stark Early Elberta is the finest peach I have ever seen. It is a thrifty grower and bore two years after setting out. The fruit is delicious and $\mathrm{I}$ think it the very best variety.-George A. Butt, Greene Co., Ark.

A Test By an Illinois Scientist.-A few years ago you people sent me a little tree of Early Elberta and it did well and made a fine growth the first year, so I took some buds and set them on a nice, thrifty Capt. Ede. I set two limbs of the Early Elberta, two limbs of the old Elberta and left two limbs of the Ede. This year all three of the varieties fruited heavily and I sprayed it well and thinned the fruit to about 5 inches. I cultivated well and the fruit was the finest I ever saw. The Early Elberta ripened eight days before the old Elberta and the Ede ripened at the same time of the latter.-Geo. W. Endicott, Pulaski Co., Ill.

An Opinion of a Grower with a Nation-Wide Reputation.-The form of Stark Early Elberta, while somewhat of the Elberta type, is rounder and I like it better for both ease in packing and attractive appearance in the box. The stem cavity is rather shallow and finely modeled, and they part from the stem perfectly without breaking the skin. The apex is somewhat sunken in a short shallow suture that gives to the fruit an appearance of high character. The coloring is peculiar; the delicate blending of a rich yellow with the crimson and deeper red is beautiful-much more refined and pleasing to the eye than the old Elberta that looks coarse beside it. When cut, the two peaches present somewhat similar characteristics, but as one would expect from its outside beauty, the Early Elberta has a much finer texture, the color about the seed a lighter shade of red, and though a perfect freestone, the flesh fills every crease and groove of the pit. In juiciness and flavor the two varieties are similar, but Early Elberta is sweeter and more satisfying. After careful comparison, I have no hesitation in giving a decided preference, as a market peach, to this Princess Royal of the old blood.-Frank Femmons, Madera Co., Calif.

Better Payer Than Elberta.-Stark Early Elberta is fine; ripe and gone two weeks ahead of Elberta (Queen). On account of superiority in quality and early ripening, I sold them for $\$ 1.50$. I am selling old Elberta for $\$ 1.00$, and both in the same orchard. I regard Early Elberta as an extra money-maker and fine for home use.-A. N. Nesbitt, Humphreys Co., Tenn.

The Finest Yellow Freestone.-Stark Early Elberta in full bearing with common Elberta planted alongside of it. I consider it the very finest yellow freestone I have ever seen or tasted; is superior to old Elberta in every way; decidedly better quality, fine grained, and best keeper of any yellow freestone. One strong point is that it turns yellow all over before it softens, which makes it a great peach for shipping; ripens about a week earlier than Elberta.-F. L. Phelps, Amatilla Co., Oreg.

No Fuzz.-The quality of Stark Early Elberta peach was extra good this year. They ripen here about June 15th. There was no fuzz on any of the peaches. You may book my order for an additional 40.-C. S. Bentley, Perry Co., Miss.

Famous Peach Authority Thinks Stark Early Elberta the Finest Peach He Ever Saw.-Stark Early Elberta that I grew in Roswell, N. Mlex., two years ago were of extra high quality and very large, averaging fully 3 inches in diameter and some going to $3 \frac{1}{2}$ inches. I think it, confuldy 3 inches in diameter and some going to $31 / 2$ inches. I think it, conParker Earle, Ex-President American Horticultural Society, Los Angeles, Co., Calif. 
Of Incalculable Value.-Am much impressed with the value of Stark Early Elberta. As grown here at Artesia, it is many points superior to Elberta. Its beauty, delicious, fine grained meat, and wonderful keeping qualities, combined with the fact that it comes at a time when we can get the highest market price, makes its value to us incalculable.-R. M. Love, Eddy Co., N. Mex.

Vastly Better Than Elberta.-They are mighty fine peaches. I peeled one by pulling the skin off with my fingers and when the peach was peeled it showed no sign of being bruised by the operation. Early Elberta is the only peach to my knowledge that remains firm enough when fully ripe to do this, yet they are juicy and high flavored. I wish to assure you that this variety is doing even better with me than Elberta; large in size and more highly colored, the sun exposed side being entirely covered with a bright carmine. In flavor it is vastly better. Measured 3 inches the narrow way and $31 / 2$ inches in length.-Joseph Gerardi, Jersey Co., Ill.

Very Rich in Flavor.- This year is the first year my Stark Early Elberta has borne. I had the finest Early Elberta in the country. They were about as large around as a pint cup and very rich flavor. I think it far superior to old Elberta. Ripens about two weeks earlier; a good shipper.W. W. Burchfield, Major Co., Okla.

Ripe When Markets Are Good.-Had growers in this country planted Early Elberta instead of Elberta they would be thousands of dollars ahead. Early Elberta comes at a time when there are no yellow freestones on the market and bring fancy prices, while the Elbertas came in a bunch and many of them sold cheap.-T. H. Atkinson, Chelan Co., Wash.

No Room for Improvement.-This peach is good in every respect; can't see any fault. Good-very good; can't think of any improvement. Geo. R. Hamilton, Allegany Co., Md.

In New Jersey.-My Early Elberta trees have fruited two years, very full. One of the best peaches for its.season of the year. Ripens long ahead of Elbertas.-David H. Tice, Berger Co., N. J.

Brings Sensational Prices.-Stark Early Elberta sold in Mt. Sterling, as high as $\$ 6.00$ a bushel.-C. E. Barnett, Brown Co., Ill.

Bore at Two Years.-My Stark Early Elberta trees bore their first crop at two years. This peach is the hardiest, most profitable and superior in quality to any other.-O.J. Taylor, M. D., Sedgwick, Kans.

Tree Folds Fruit. - Stark Early Elbertas were the only trees that gave us peaches last summer. Held fruit where others dropped. Very fine.John Kintz, Orange Co., N. Y.

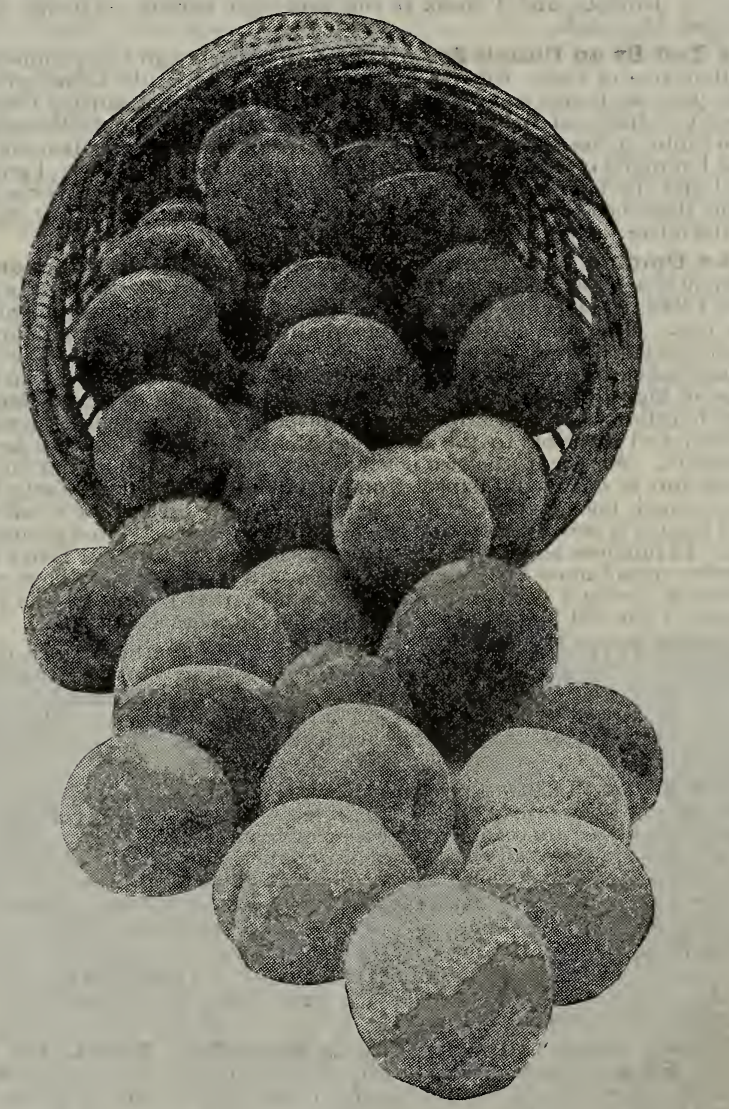

Stark Early Elbertas-Last Year We Sold Out Early-Turned Down Orders for Thousands of Trees. Reserve Yours Today-Now. 


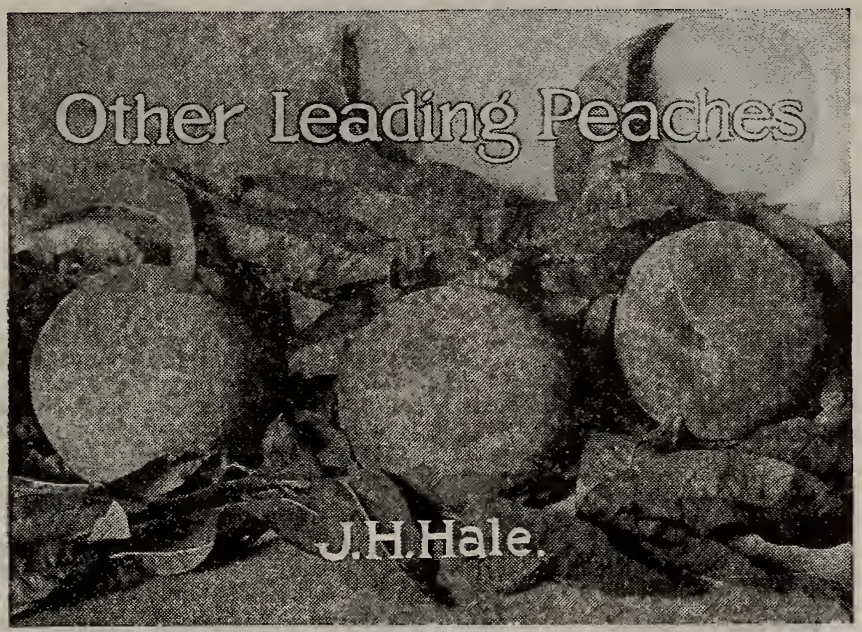

\section{The Best Peaches-Selected After One Hundred Years of Growing and Testing}

Every variety described in this book has been selected with greatest care. Every one is of superior worth-the best we have tested in our 100 years experience. In their selection we have considered not only our own, but also the combined experience of America's Leading Peach Growers.

Beginning with Mayflower-the earliest peach-all sorts are arranged according to their season of ripening, Krummel October being the latest good sort. Stark Early Elberta, described in first half of booklet, is out of its place; it ripens just ahead of Crawford Early Improved.

Following each description we use capital letters to designate the locality to which the variety is adapted. S, means South; C, Central; N, North; NN, Far North. Thus a variety carrying the letters, NCS, is suited to Northern, Central and Southern territory. Those carrying $\mathrm{NN}$ are the hardiest and can be planted along the extreme northern line of the peach belt.

Mayflower. The earliest peach to ripen; a semi-cling that is ay almost overspread with a beautiful flashing red. The tree is hardy and reliable and the fruit ships remarkably well for an early peach. Unlike Sneed, Triumph, Hale's Early and some other early sorts, it is not soft and watery, but holds up well. The best extremely early peach with the exception of Red Bird. Ripens about fifty days before Elberta. NCS

\$3.50 Per Crate.-The J. Van Lindley Co., of Pomona, N. C., had several hundred three-peck crates which averaged $\$ 3.50$ per crate. It is red all over and brings fancy prices. - Rural New-Yorker.

Red Bird Cling. The profit to growers of Red Bird Cling almost unbelievable within the past few years have been almost unerever offered for sale they bring double and treble the prices of other early sorts. It has not the shortcomings of other varieties of its season; the flesh is solid, the skin is strong and it ships well, the quality is good, and it is of enormous size and wonderfully beautiful. The tree is a strong grower with luxuriant foliage, and it bears great crops every year. It is extremely hardy, and can be depended upon for full crops when many of the old favorites are failures. We recommend it as the best of the extremely early sorts. Grow Red Bird Cling for profit; the advent of this glorious peach makes possible tremendous profits. The growing of small, watery, poor quality early peaches, such as the markets have always known, is being discontinued as growers learn of the prices secured for Red Bird. Ripens about forty-five days before Elberta. NNCS

Six Dollars A Bushel.--Red Bird Cling is making wonderful records every year, now selling for from $\$ 4.00$ to $\$ 6.00$ per bushel by carload.E. W. Kirkpatrick, Holland Co., Texas. 


\section{Stark Bro's Nurseries}

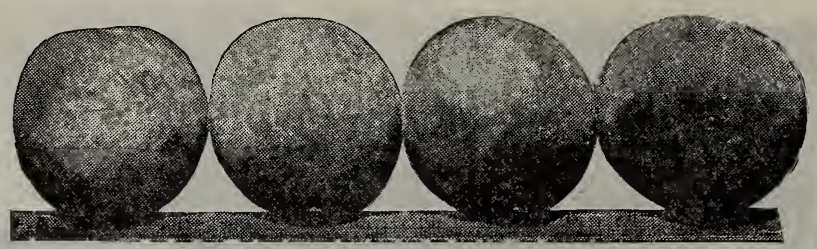

Red Bird Cling - Enormous, Four Cover a Foot Rule-Best Very Early

Peach. Red as Blood-Always in Demand on the Markets.

Five Dollars a Bushel.-Mr. Jefferies sends me a postal saying that he sold Red Bird Cling peaches as high as $\$ 5.00$ per bushel and averaged $\$ 225$ per bushel for his entire crop. His Elberta averaged 79 cents per bushel. I also have a statement from an Alma, Arkansas shipper, saying he averaged $\$ 2.25$ per bushel for his Red Bird Cling peaches. This peach has a record here of not failing to bear in six years.-J. D. Reinhardt, Crawford Co., Ark.

A previous season Mr. Jefferies sold his Red Bird Cling at record breaking prices, averaging him over $\$ 10.00$ per bushel.-Stark Bros.

All Others Failed.-Red Bird Cling doing nicely-fruited well last year when nearly all other varieties were killed by the hard winter. They sell well with us - grand lookers.-J. W. Bell \& Son, Chautauqua Co., N. Y.

Extremely Hardy.- Red Bird certainly is a fine peach. Meat very fine; large size; fine quality. It proved hardy in bud this season; everything but it and Alton were killed.-H. D. Morton, Pope Co., Ark.

Three Times the Price.-Last year I sold the IGreensboro, Belle of Georgia and other peaches for 35 cents per basket and the Red Bird Cling brought from $\$ 1.00$ to $\$ 1.25$ per basket. This is the reason I bought so many trees of the Red Bird Cling.-Dr. E. L. Morris, Fayette Co., Tenn.

Better Shipper Than Elberta.-Four years ago I purchased from you some Red Bird trees and from 175 trees I sold $\$ 442.00$ worth of fruit this year besides giving many bushels to my neighbors. The Red Bird is a better shipper than any other peach, Elberta not excepted.-W. A. Hill, Johnson Co., Ark.

Sixteen Carloads.-F. W. Brockman Commission Co., of St. Louis, sold 16 carloads of Red Bird Cling from Texas. These averaged $\$ 793.10$ pęr car of 400 bushels or $\$ 1.981 / 2$ per bushel.-Kansas City Packer.

Two Dollars a Crate.-Red Bird Cling sold on Kansas City markets for $\$ 2.00$ per four-basket crate.-Kansas City Packer.

The Wonder Peach of Texas.--Red Bird Cling from 75 trees brought $\$ 413.50$. - R. F. Kietar, Smith Co., Texas.

Most Profitable Early Peach.-Very large and fine; brings $\$ 1.50$ to $\$ 1.60$ per bushel when Greensboro bringing $\$ 1.25$. Undoubtedly the most profitable of all the very early peaches.-B. Carine, Conn.

June Elberta. Looks very much like Elberta and on the fruit stand it is most attractive. Ready to go on the market immediately following Red Bird. We consider this big, early yellow peach most valuable. It is a good sort to come in ahead of Stark Early Elberta and is always welcomed by the fruit man, as it is the first profitable yellow peach to ripen. Growers can always depend on this sort to bring top prices. Ripens about twenty-seven days ahead of Elberta. NNCS

Making Great Record in Largest Connecticut Orchard.-Showing up in splendid shape. One of the heaviest bearers in my orchard-a great money-maker.-B. Carine, South Glastonbury, Conn.

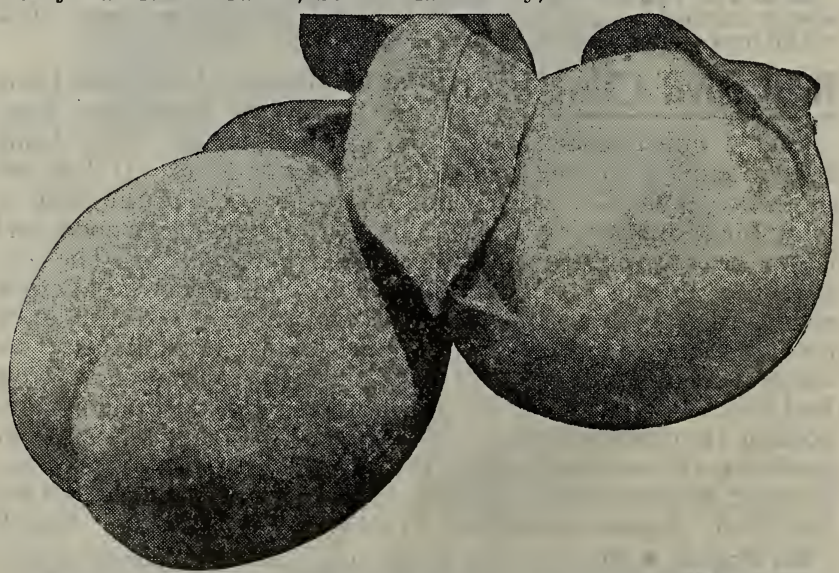

Red Bird is Making Peach Growers Fortunes-Often Brings $\$ 6.00$ a Bushel. A Loaded Tree, all Fiery Red, is a Wondrous Sight. 
Eureka. Year in and year out we belive Eureka will bear more fine peaches than any other variety. This great ironclad peach has proved absolutely the hardiest, after fifteen years' test. Bears so full it needs thinning when Elberta all killed. In 1912, 32 degrees below zero killed all buds of all other sorts, yet every Eureka tree in our test orchard bloomed. Good size, almost as large as Alton, and a week earlier. Beautiful red cheek; better flavor and redder than Carman; firmer, better keeper and better shipper with far less brown rot-in fact, almost free from brown rot. The planting of Eureka is on the increase. Ripens about thirty-five days before Elberta. NNCS

Early Mamie Ross. Ripens a little earlier than the old Fos. strain and is larger and finer looking. Following our plan of improvement we are advising this strain which has proven the best of the Mamie Ross type. Ripens thirty-two days ahead of Elberta. NCS

Alton. There are five great varieties of white peaches ripening ahead of Elberta-Alton, Carman, Champion, Eureka and Belle of Georgia. Of all these, Alton is in the lead-the prince of white peaches. Its rosy, red cheek with its background of creamy white, its sweet and luscious flavor, the hardiness of its bloom and its unsurpassed bearing habit, has made it a general favorite. We have long recognized its value and about fifteen years ago began featuring it on the advice of $\mathbf{E}$. H. Riehl, of Alton, Ill., Director of the Ill. Experiment Station. The growth of its popularity has been remarkable and we are growing them by the train load and advising their planting along with Stark Early Elberta and other leaders. Ripens thirty days before Elberta. NNCS

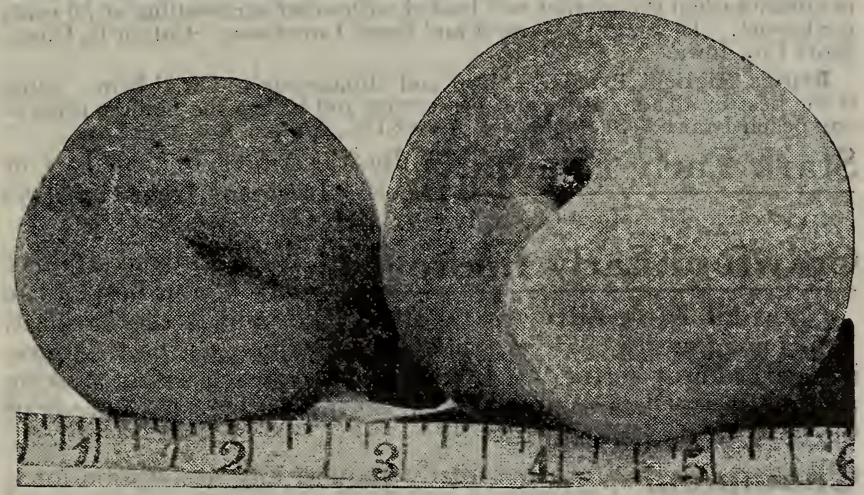

The Large Peach is Alton, the Other Carman. Alton is the Best Quality and Most Profitable of All White Freestones.

Far Better Than Carman.-As compared to Carman, it is hardier, does not rot as badly, is a better shipper, and brings better prices. The tree is a better bearer and is more vigorous.- $B$. Carine, Conn.

Two Dollars a Basket.-Alton peach bore last year when all others failed. Six baskets from two small trees netted $\$ 12.50-E$. J. Breech, Northampton Co., Pa.

Very Large.-My three-year-old Alton trees produced $\$ 8.00$ per tree. The peaches averaged $3 / 4$ of a pound.-J. T. Giles, Washington Co., Tenn.

Customers Fight for Them.--Sold Alton this summer by the wagon load at $\$ 1.50$ per bushel, and people simply fought for them. Later: Am glad to know Alton has so well justified my estimate of it. Think I can claim to have rescued it from oblivion and think I did a good deed when I did so.-E. A. Riehl, Madison Co., Ill.

Only Variety That Bore.-A good crop of Alton; do not believe there was another peach in the country.-John A. Butler, Montgomery Co., Mid.

Brings Best Prices.-You cannot say too much for Alton for this locality, where we are almost sure to get a late frost, which kills Elberta and like varieties. We get more for Alton than for Elberta. Alton stands shipping well.-H. B. Pepmiller, Ripley Co., Mo.

Bore heavily this year-simply fine.-Mrs. J. C. Davis, Lucas Co., Iowa.

Hardy as a seedling here; delicious.-J. M. Cook, Washington Co., Ark.

Ships from Ocean to Ocean.-Alton the greatest peach of its season. Its color, size and flavor will make it sell in any market. It will ship, in my opinion, better than any other variety. If properly picked and packed you could ship across the United States.-C. A. Zollinger, Buchanan Co., Mo.

Brings Five Cents Each.-Alton are the finest July peach in existence; larger than Carman. I sold Alton here for five cents each, or fifty cents a dozen.-Dr. E L. Morris, Fayette Co., Tenn. 


\section{Stark Bro's Nurseries}

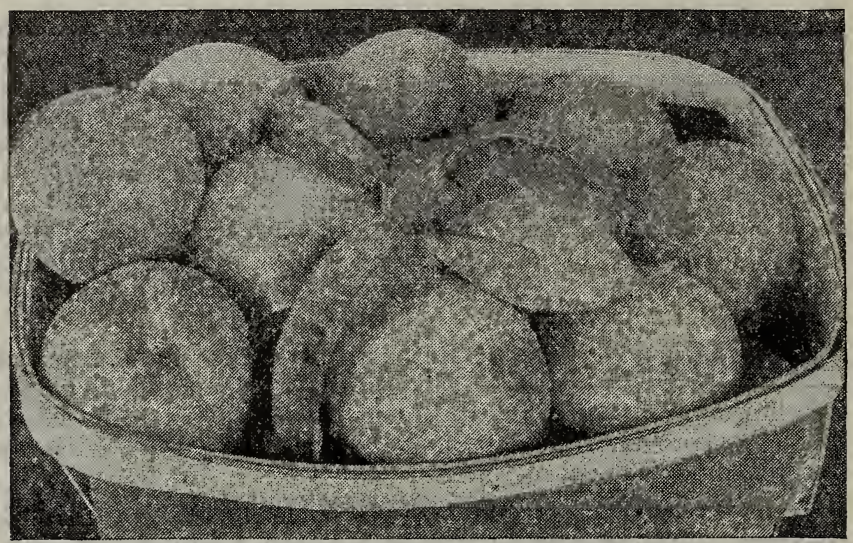

Alton-Prince of All White Peaches. On the Market its Rosy-red Cheek and Luscious Flavor Command Top Prices.

Bear Every Year.-Last year Alton was loaded with fruit while in next row trees of other kinds did not have one peach.-Jas. Gaines, Vermillion Co., Ill.

Forty Cents a Dozen.-Last fall I sold Alton peaches to fruit dealers at 40 cents a dozen.-Elmer Grandin, St. Louis, Mo.

Will Stand More Cold.-Nothing beat Alton, Belle of Georgia, Red Bird Cling and Elberta. Alton and Red Bird Cling are the surest croppers, Will stand more cold than any peaches I have ever seen.-J. T. Giles. Washington, Co., Tenn.

Brings Three Times as Much.-I sold my Alton and Illinois at $\$ 1.50$ per bushel when the market was loaded with other sorts selling at 50 cents per bushel. They are the largest and finest I ever saw.-Calvin R. Clark, Scott Co., Iowa.

Brings Highest Prices.-Alton and Illinois succeed well here. Alton is the best of all for eating and preserving and brings the highest price of any peach I raise.-S. S. Haswell, Essex Co., Mass.

Stark Early Elberta. Fully described in first half of book. It ripens from ten days to two weeks before Old Elberta. NNCS

Crawford Early Improved. This improved strain of

Crawford Early-Reeve's favorite type, and is the hardiest. It has not the shy bearing habit of its relatives; as the tree ages, it seems to bear better. It is a deep yellow peach with a striking red cheek and has a sweet and pleasant flavor. Ripens about ten days before Elberta. NCS

Champion. Does not really require any description for it is known everywhere as one of the hardiest and

best peaches in existence. It is creamy white with a rosy cheek, and is nearly as highly colored as Alton. The flesh is firm, sweet, rich, and satisfying and it ships well to distant markets. It is popular in Texas and throughout the South, and its hardiness has made it a general favorite along the Northern line of the peach belt. It is ripe about twenty days later than Alton. These two varieties are splendid sorts to plant for all markets. Handsome white peaches always bring good prices. Ripens about nine days before Elberta. NNCS

Immense Size.-Champion peaches grown here measured 11 inches in circumference and weighed $3 / 4$ pound.-Geo. T. Powell, Pres. Agricultural Expert Asso., Long Island.

For quality Champion is one of the best white peaches.-Dr. J.D. Kales, Chicago.

Retains Its Flavor.-This is another money-maker. Its extreme hardiness and productiveness render it a never-failing source of profit. I have never known this variety to fail. Its fruit is always so large, so beautiful, of such high quality, that it always commands a ready market at the highest prices. It is the favorite with all lovers of good fruit. As a canning peach it has few equals and no superior, retaining its flavor indefinitely.Western N. Y. Hort. Society.

Belle of Georgia. Its hardiness has made it popular. It is of a rich, creamy white, brightly

blushed on the sunny side. It is of good quality but not so good as Alton; ships well and sells well; can be depended on much farther North than Elberta. Ripens about eight days before Elberta. NNCS 
Elberta Cling. A perfect clingstone of tremendous size and as round as an orange. It has beauty,

quality and no peach will ship better. It is an Elberta in appearance and will instantly attract attention on any market; the best all around yellow cling and has made money for growers everywhere. The tree is thoroughly dependable and a sure and heavy cropper. Wherever a yellow clingstone is wanted plant Elberta Cling. It never disappoints. Ripens about four days before Elberta. NCS Capt. Ede. A very handsome yellow peach that much is better in quality. It is ready to come off of the trees two or three days earlier than Elberta and side by side with this old well-known favorite it will bear oftener because it is hardier. Capt. Ede has slowly grown in favor for the past ten years and now ranks with the very best yellow market kinds. Ripens two or three days before Elberta. NCS

Elberta. (Queen) The most widely grown yellow peach, and for years the greatest money-maker. The tree is

thrifty; bears tremendous crops and is fairly hardy. The name has become a household word wherever peaches are bought and sold. It is a beautiful yellow sort of splendid size and attractively blushed. It carries well, and if proper care is given to picking, packing and shipping, the Elberta nearly always goes on the market in good condition. Its quality is its weakness, as it is not first-class; for this reason peach growers have been looking forward to the time when a variety of good quality with the Elberta's good points would be found. We searched for such a peach for years, and finally found in a Utah orchard a variety ripening about ten days earlier, that in ten years of testing has proven to be the most perfect yellow market peach. We named it Stark Early Elberta, and it has proven even more than we had hoped for it. It brings sensational prices every season and the commercial planting of Elberta is declining as this wonder peach becomes known. NCS

My Elberta Queens bought from you, are a far better strain than ordinary Elbertas grown by others around Marionville, who bought their trees from other nurseries. Their Elbertas are thinner, narrower, and more pointed, while mine are large, round and fat looking and bring me at least 50 cents more per bushel than their strain of Elbertas.

From 20 Acres of Elbertas I harvested 4800 bushels of peaches, which sold as high as $\$ 1.75$ and averaged $\$ 1.60$ per bushel or more, for first-class fruit. They brought this price right on the track. I did not have to pay any freight charges or incidental expenses after $I$ delivered them on the track.

Krummel October is a great peach. This season they were the largest I ever saw and marvelously beautiful. I got $\$ 2.00$ per bushel for them. The Weber Meat \& Produce Company is one of the finest stores in Kansas City. I sent them some Krummel and they wanted a lot more of them, but I had already sold out. They said, they were the finest they had ever seen.-U. L. Coleman, Lawrence Co., Mo.

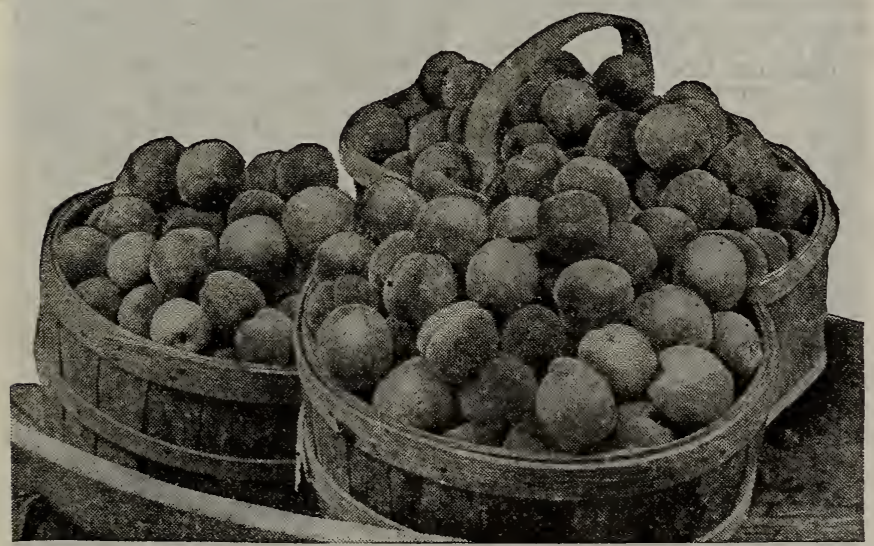

Elberta Queen-Coleman Gets 50c More a Bushel for our Select Strain of this famous Commercial Peach than others who bought trees elsewhere. 


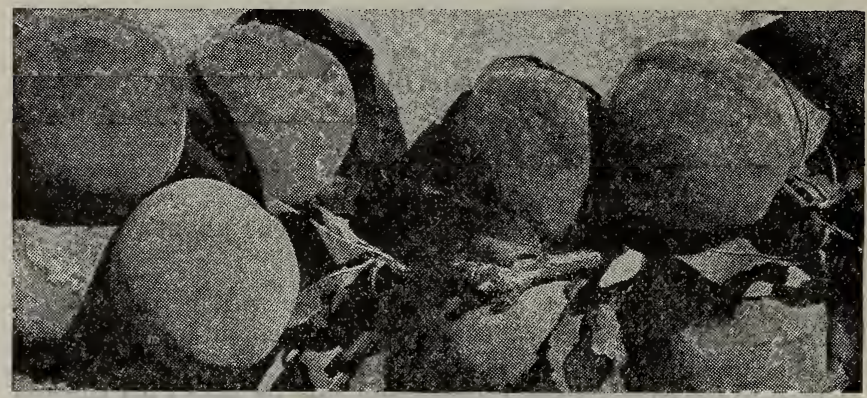

J. H. Hale has Made Good. Cluster shows how full Stark Bro's J. H. Hale Trees bore in their Louisiana, Mo., Orchards.

J. H. Hale. We now offer it at Planters Prices. We recommend the planting of the J.H. Hale peach in preference to old Elberta Queen. It is a very promising peach of the Elberta season and is a good sort for planting to follow Stark Early Elberta, ripening as it does ten days after stark Early Elberta-practically with Elberta.

The J. H. Hale is better than the old Elberta, as a profit producer. The J. H. Hale is to peaches what Black Ben is to apples -a splendid shipper of enormous size, a heavy bearer, very showy and while not of the same high quality as Stark Early Elberta, it is a great money maker. You will never regret planting the $\mathrm{J}$. H. Hale. We have tested it in our orchards at Louisiana, Mo., as is our unvarying custom with all new fruits.

The J.H. Hale is a globular, freestone peach, larger than Elberta, yellow color, almost entirely covered with bright red, thick skin and has practically no fuzz. The flesh is solid, thus making it an excellent shipper. The quality of the J. H. Hale is fairly good, although inferior to Stark Early Elberta which undoubtedly is the highest quality and most profitable yellow peach grown.

President Bert Johnson of the Arkansas Horticultural Society, who is one of the most successful and largest peach growers in America, has thousands of acres of peach orchards. President Johnson thinks highly of the J. H. Hale as he told our Mr. Stark at the 1914 meeting of the Arkansas Horticultural Society that his faith in this peach was founded on a single visit of his partner to Mr. Hale's bearing orchards in 1913 when the J. H. Hale was ripe. So favorable was the report on this peach that Mr. Johnson planted 10,000 J. H. Hale. Ripens with Elberta. NCS

GUARAN TEE. We absolutely guarantee our J. H. Hale trees to be true to name and fully up to the high standard of Stark Bro's Quality. Our record of 100 years of successful tree growing is back of every Stark Tree. We now offer J. H. Hale trees at Planters low prices.

A Splendid Keeper.-You will be interested in knowing that of the two specimens of J. H. Hale grown in Louisiana, Mo., which you sent me sometime ago, one specimen remained here on my desk sixteen days. It was in first-class condition in every way. Its flavor was just as good as ever. -E. H. Favor, Editor Fruit Grower and Farmer, St. Joseph, Mo.

Missouri Grown Just Right for Market. - The specimens of J. H. Hale as grown at Louisiana, Mo., on your farm are certainly a beautiful yellow and red color and large enough in size to be just right for market or for any use at home. The flavor is good and ought to please any one. They came in good condition.-H. E. Van Deman, Ex. U. S. Pomologist.

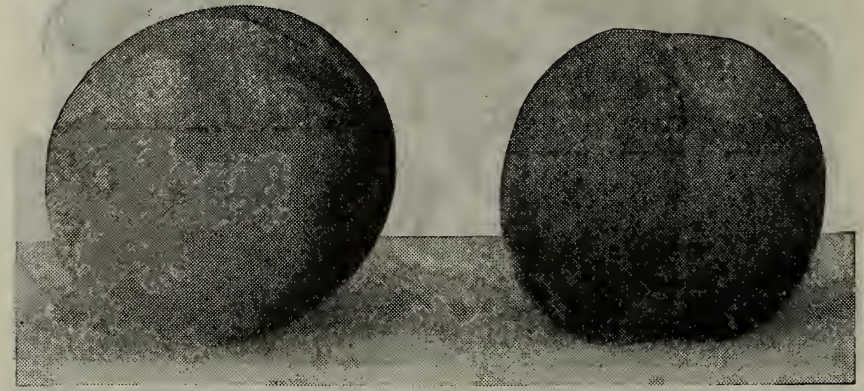

Stark Early Elberta on the left from Sumner Gleason, Originator. J. H. Hale on the right from Mr. Hale's Orchards, Photographed by Mr. Stark. 
100 Years at Louisiana, Mo.

Washington. This thoroughly good white peach is an old time favorite and should be planted in every home orchard. Its vigor and hardiness insures it a lasting place on the list of good peaches. Ripens about eight days after Elberta. NCS

Illinois. A big pink and white peach that ripens after Elberta 1hois. It is juicy, spicy and highly flavored, and E. H. Riehl, the originator, has always claimed that it surpassed Champion. It is a hardy sort and can be safely planted along the Northern limit of the peach belt. Illinois should be a part of every home orchard and whenever a white peach is to be planted commercially should not be overlooked. Ripens about eight days after Elberta. NCS

Astounding in Size.-The Illinois peach trees I got from you have borne peaches simply astounding in size.-W. C. Squier, Calhoun Co., Mich.

Ioaded When Others Fail.-Illinois peach trees in my orchard loaded when other sorts failed to bear crop.-J. D. Hofreiter, Tazewell Co., Ill

Best of Its Class.- I cannot but regard it as far superior to anything else in its class. Preferred to Champion, more attractive and more valuable. Later: Compared to Champion it is more hardy and of better quality Champion failed here this season. Illinois took a partial rest with only a light crop.-E. H. Riehl, Illinois Experiment Station.

A Wonder in New Jersey.-Illinois peach is a wonder. I had seventeen quarts from two two-year-trees and thinned half at that. Alton is good, but can't compare in productiveness or quality.-B. O. Bogert, Bergen Co., N. J.

Engle Mammoth. Round and yellow and of tremendous size; one of the most attractive peaches on the entire list. Its hardiness has made it popular in Michigan and in other northern sections, as well as in the Southern and Central States. Its season is immediately following. Elberta; it is of better quality than that old favorite. Ripens about ten days after Elberta. NNCS

Engle Mammoth we consider among our best.-Dr. J. D. Kales, Chicago. Could I grow but one variety: would choose Engle Mammoth.-J. L. Hilborn, Leamington, Ont., Can.

The very best peach of its season; of large size, attractive appearance, best quality, very productive.-Michigan Experiment Station.

Most Valuable in Michigan. - The Engle, as I saw it fruiting in the South Haven, Michigan, Experiment Station, is bearing far better than any of the numerous varieties, and pronounced more valuable in the Station Orchard.-H. L. Reed, Pike Co., No.

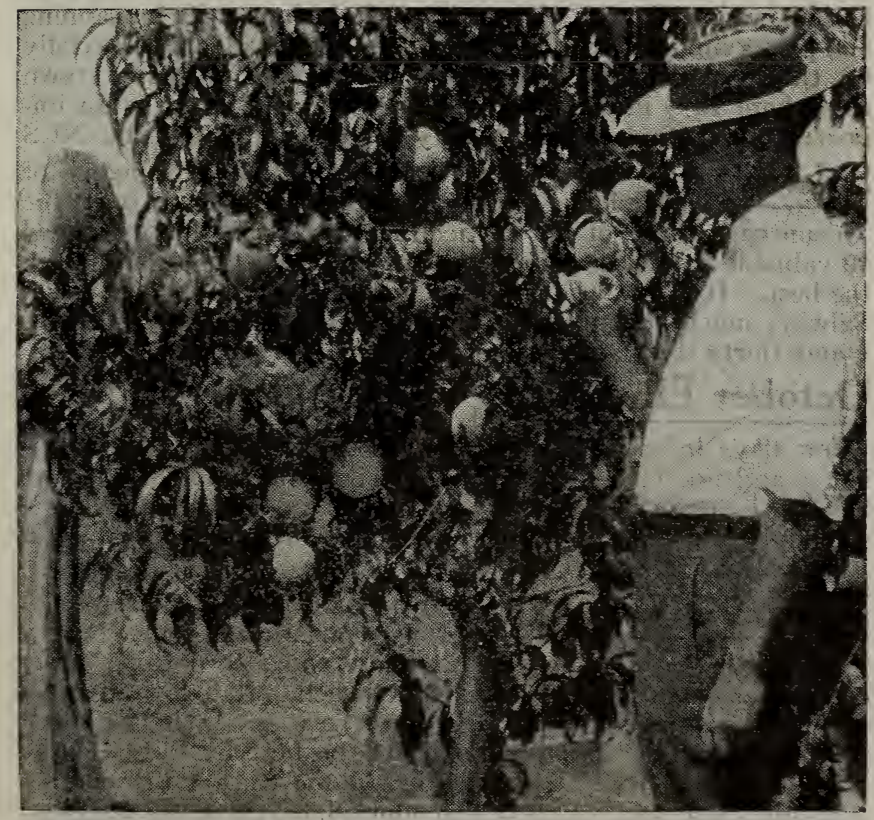

Enormous J. H. Hale Peaches - Tree 3 years old from Bud in Stark Bro's Orchards at Louisiana, Mo. Except in Mr. Hale's Own Orchards, Stark Bro's are undoubtedly the first Nurserymen in America to fruit J. H. Hale. 


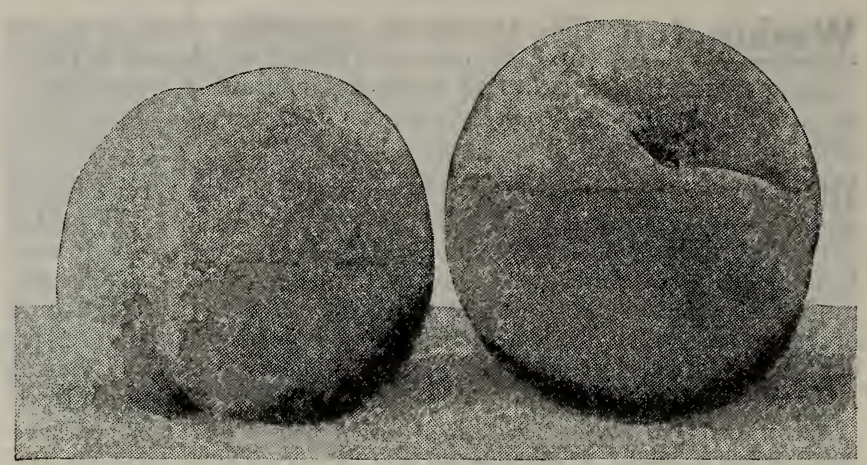
Krummel October; Most Beautiful, Most Delicious and Most
Profitable Late Peach.

Crawford Late Improved. Our strain of Crawford Late is large, of better quality and the tree hardier and a surer bearer than old Crawford Late. It is one of the very best of late yellow peaches for kitchen use, eating out of hand and for profit on the market. It is large and yellow with a bright red blush. They are largely grown and are found on the markets everywhere. Ripens about twelve days before Elberta. NCS

The Very Best.-I find this peach to be very fine, a heavy bearer and fruit the very best.-Obe Lash, Fulton Co., III.

Late Elberta. When Elberta and Crawford Late are off the market there is a season when big yellow peaches are scarce. Just at this time Late Elberta is ready to ship. It looks and tastes much like Elberta and is just what the name implies - an Elberta that ripens late. It is being planted commercially with June Elberta, Stark Early Elberta, Elberta Queen and October Elberta. These five sorts enable the orchardists to have yellow peaches for the markets from early till late. Ripens about twenty-five days after Elberta. NCS

Mammoth Heath Cling. A smooth, clean, creamy white blushed, clingstone peach that is known and valued for its tender, melting flesh and its luscious flavor. A favorite with the housewife for canning and preserving; commands fancy prices and is valuable especially for the local market. They are of great size; we have grown them here $101 / 2$ inches in circumference. Our strain is an improved one. Ripens about twenty-five days after Elberta. NCS Salway. (Holsinger Strain) Major Frank Holsinger, of country because of his horticultural activities, has produced 49 valuable Salway seedlings, but the one we list is far and away the best. It is just what its name implies, an improvement over Salway, much resembling Elberta but better quality. Ripens about thirty days after Elberta. NCS

October Elberta. Really better in quality than Elberta and somewhat larger. Ripens just a

few days before Krummel October and is highly flavoredsweet and not bitter at the pit. It is a valuable sort but we believe Krummel October better. It ships well and makes a splendid appearance. Ripens about thirty-five days after Elberta. NCS

Krummel October. A great money-making late peach.

Its enormous size and golden beauty

insures highest prices. In hardiness and size nothing of its season can compare with this great peach. It has the paying habit of bearing every year and to those who want a late peach we recommend Krummel October as the best by far. On the St. Louis market it has always co mmanded higher prices than any other late sort. It is of splendid quality, fine texture, with no bitterness around the pit. The tree is a strong grower, vigorous, healthy and bears young. Years of testing have proven it to be one of the most dependable and it ranks among the very 
hardiest. Everywhere-east, west, north and south-it is the queen of late peaches and no variety on the entire list is more profitable. The demand for October peaches is always far in excess of the supply. They do not find so much competition on the market and the fruit brings more dollars. Ripens about thirty-eight days after Elberta. NNCS

Best Late Peach.-If I ever plant another orchard I will plant onefourth of them Krummel October. I never knew before that any peach would ripen and hang on the tree for weeks without rotting. If you have another variety that even equals this I would like to try it.-A. C. Zollinger, Buchanan Co., Mo.

Fine in Arizona.- - One of the very finest peaches for Arizona.-John A. Bandele, San Simon, Ark.

Hang Until Freezing Weather--Your Krummel October has the world beat for late peaches. I had big fine peaches hang on the trees until they froze. Mammoth Heath Cling are also good; the whole town wanted them.-W. R. Cobb, Buchanan Co., Mo.

Last Good Yellow Peach.-They are the best late peach I know. The tree is thrifty, a strong grower and the last good yellow peach to ripen.J. P. R. Hall, San Diego, Co., Calif.

Better than Salway.--Very fine peach-better than Salway.-J. B. Peterson, Sonoma Co., Calif.

By far the best late peach.-Hall Bros., Maricopa Co., Ariz.

The best paying peach I know.-N. Waterhout, St. Louis Co., Mo.

Is easily champion of them all.--Joseph Gerardi, Jersey Co., Iil.

Latest Freestone.-Quality good, refreshing, though a little acid. The latest freestone grown at the station; bore sparingly on young trees. Promising.--Ohio Exp. Station.

Very good; one of the latest; valuable.-Ill. Experimental Station.

The Originator's Description.-Always ripens several days later than Salway - from six to twelve days according to season. Better than Salway in every way - size, shape, color. Does not rot as badly as Salway; hangs better, averages larger in size, in fact a better peach in every respect.-N. Waterhout, St. Louis Co., Mo.

Nothing Can Equal Krummel for its season. It is one of the hardiest yellow sorts and always brings good prices on the market. It is the most profitable late sort.-B. Carine, Conn.

Finest They Ever Saw.-Krummel October, is a great peach. This season they were the largest I ever saw and marvelously beautiful. I got $\$ 2.00$ per bushel for them. The Weber Meat \& Produce Company is one of the finest stores in Kansas City. I sent them some Krummel and they wanted a lot more of them, but I had already sold out. They said, they were the finest they had ever seen.-U. L. Coleman, Lawrence Co. Mo.

Big Peach Profits. -Wm. List, Hamilton Co., Tennessee, is proprietor of the Valley View Fruit Farm consisting of 3,500 peach trees which produced the fourth year, 3,500 crates: 10,000 crates in 1913 (the 5th year) and this year Mr. List reports a crop of about 7,500 crates. (A crate consists of six baskets and averages from $\$ 1.00$ to $\$ 5.00$ owing to the season.)

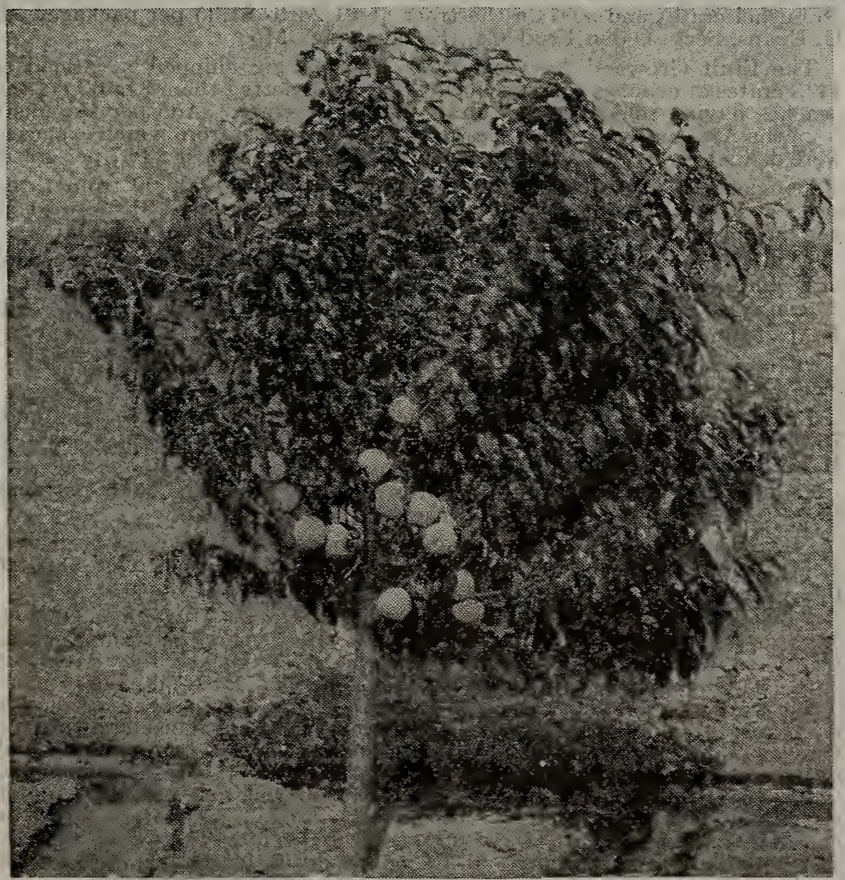

Three-Year-Old Krummel October - A Very Young Bearer. Fruits Two Years Ahead of Salway and Other Peaches of That Type. 


\section{Some Michigan Orchard Yields}

One of Michigan's large fruit growing associations has supplied figures upon several orchards in the peach belt, as follows:

W. H. Gebhart sold 2,658 bushels of peaches from 10 acres for $\$ 5,316$, or $\$ 531.60$ per acre.

Buckley \& Douglass' peach orchard has given net returns of $\$ 200$ per acre for five consecutive years.

W. A. Wright's peach orchard averaged $\$ 240$ per acre for a term of years above all expenses.

L. F. Titus realized $\$ 365$ per acre from 4 -acre peach orchard, 7 years old.

G. L. Dressel made a clear profit of $\$ 460$ from 136 trees.

F. E. Bissett produced 2700 bushels of peaches at $\$ 2.00$ per bushel, which yielded $\$ 600$ per acre.

O. W. Bramon netted $\$ 450$ per acre from peaches.

R. D. Graham netted a profit of $\$ 2,800$ from 5 acres of peaches, and over $\$ 6,000$ from 30 acres of general fruit.

Record of a Massachusetts Peach Orchard.-From $11 / 2$ acres of peach trees set very close I sold peaches amounting to $\$ 631.11$. I kept account of fertilizers, baskets, cost of hauling to the city market and hired help, and I netted \$562.28.-A. F. Tenney, Essex Co., Mass.

$\$ 463.13$ Net Per Acre from Peaches.

Ludington Patton of Koshkonong, orchard of 955 peach trees, 8 years old, harvested 1836 crates. His report follows:

955 trees eight years old . . . . . . . . . . . . . . . . . . 1836 crates.

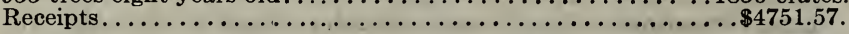

Entire Expense 1st Year:

Cultivation.........................\$ 42.00

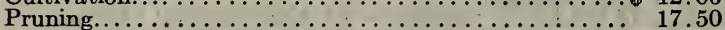

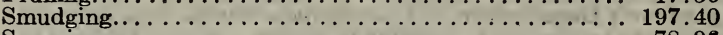

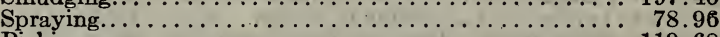

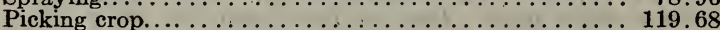

Packing crop..................................... 129.90

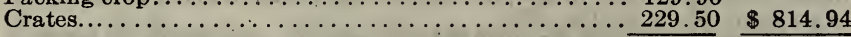

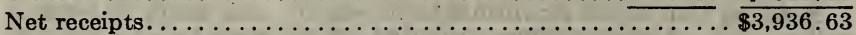

Average net profit per acre..................... 463.13

$\$ \mathbf{\$ 8 0 0 . 0 0}$ per Acre. - "Good, thrifty peach trees often bear a bushel at the 3 rd year, or 100 trees per acre averaging even 3 pecks per tree, and selling at $\$ 1.00$ per bushel (a low estimate of price), a three-year-old orchard will give a gross income of $\$ 75.00$ an acre. At four years, it may be expected to average 3 bushels per tree. Three years ago, by shipping to eastern and northern markets some growers realized as high as $\mathbf{\$ 8 0 0 . 0 0}$ per acre for their crop. During this season, peaches sold in Boston and New York for as much as $\$ 4.25$ per crate. "-Mo. State Board of Hort.

Peach Profits in Missouri.-R. M. Hitt of Koshkonong, Mo., reports one 40 acre orchard which produced 9,359 bushels of peaches. This yielded more than $\$ 100.00$ per acre. From an orchard of 35 acres 8 -yearold trees 7880 bushels of peaches were harvested. These were packed in 16 bushel crates and sold on the tract at $\$ 1.25$ to $\$ 1.35$ per package.-J. E. Evans, Secy. Olden Fruit Co., Koshkonong, Mo.

The Fruit Growers' Association of Koshkonong shipped a carload of 4443 crates of peaches to New York City which netted them $\$ 1,462.89$, the peaches having sold at more than $\mathbf{\$ 3 . 3 0}$ per crate. Another shipment from the Association to Boston sold at $\$ 4.25$ per crate from which expenses were deducted, leaving a net profit of $\$ 1,758.28$ or almost $\$ 3.37$ per crate.

Douglas Canady of Lawrence Co., Mo., cleared $\$ 1,000.00$ from three acres of Elberta peaches. He received an average price of $\$ 1.50$ to $\$ 1.75$ per bushel loaded at his station.

$\$ 5,000.00$ from fifteen acres of Krummel October peaches is the record of U. L. Coleman, of Lawrence Co., Mo.

$\$ 7,000.00$ for the crop of a 35 -acre peach orchard is the report of Col. J. M. Tanner, Clay Co., Illinois.

"One acre of peaches planted between apple trees netted \$225.00." Sleepy Creek Orchard Co., Monongalia Co., W. Va.

From 437 peach trees planted at 18 feet interval on three acres of ground, 700 bushels were harvested which sold for $\$ 1.00$ to $\$ 1.50$ per bushel. H. G. Richards \& Son, Newton Co., Mo.

The Patent Sun Proof Paint Co., Milwaukee, Wis., netted $\$ 500$ per acre from 9 acres of peaches in Southwestern Missouri.

One of the largest growers of near Frankfort, Mich., gave me his figures a short time since and they showed for lasti year's operations over $\mathbf{\$ 8 0 0 . 0 0}$ per acre net on one orchard of Elberta.-Benj. Newhall, Chicago, Ill.

5,000 Bushels from Fifteen Acres.-George R. Murray of Oregon, Mo., superintendent of horticulture at Park College three years, and whose fruit farm adjoins the town of Oregon, has just finished harvesting his crop of 5,000 bushels from an orchard of 15 acres. By producing peaches of high quality, packing them up to a rigid standard in neat, attractive packages, using only the "choice" grades for shipment, and selling the ripe fruit at home, Murray succeeded in building up a good home market and in bringing buyers right to his door. Mr. Murray is a strong believer in intensive cultivation for seasons of drought and what he has done under the abnormal and adverse conditions, with no rainfall from June 5 , is considered a marvel. He claims no special credit, however, for his success, and says there is no secret about it-simply intensive culture and 2 close study of the market.-News-Press, St. Joseph, Mo.

Every peach orchard should be at least half Stark Early Elberta 


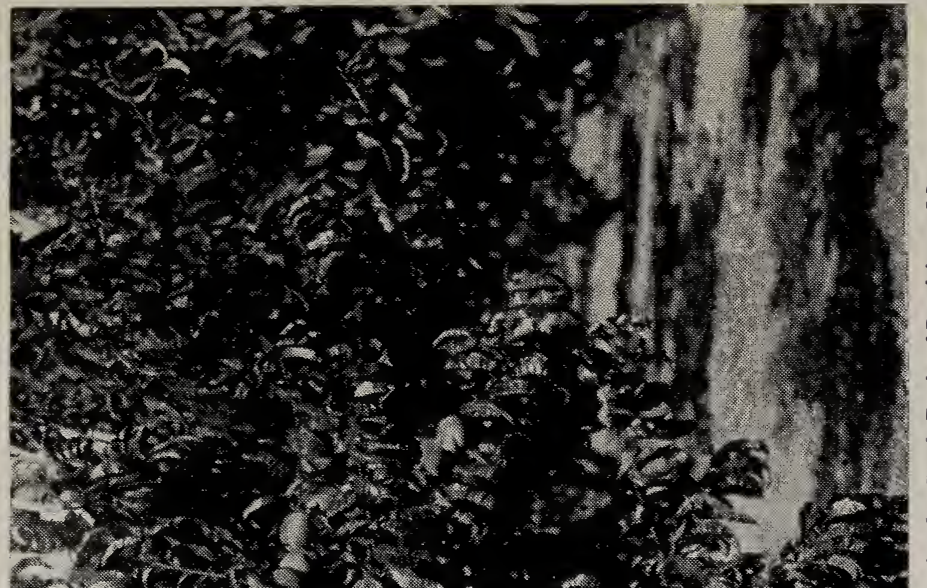

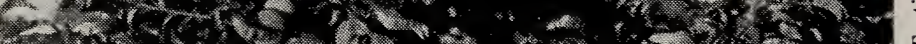

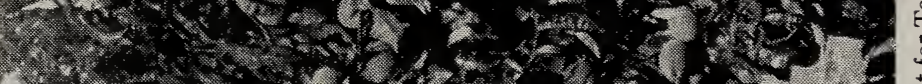

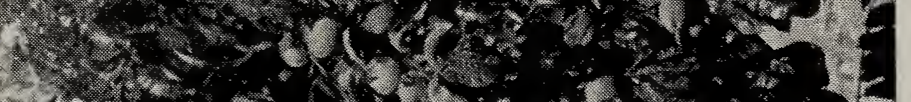

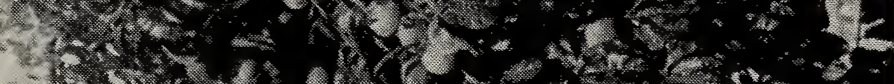

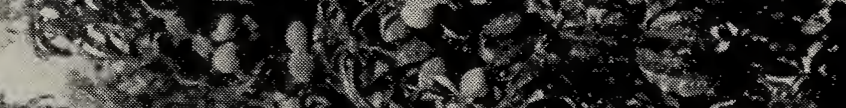

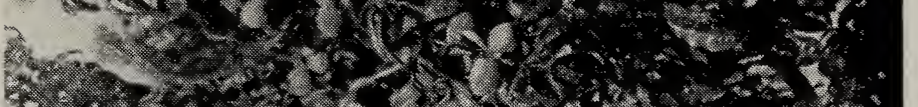

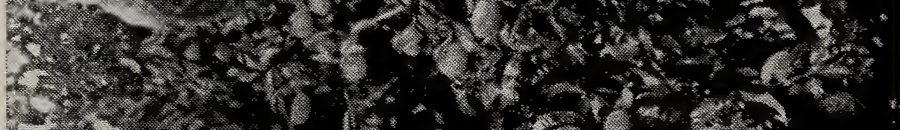

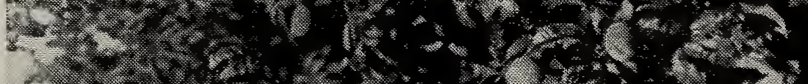

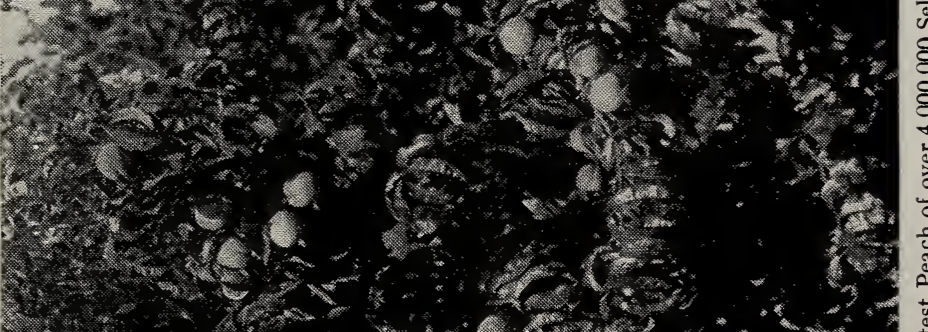

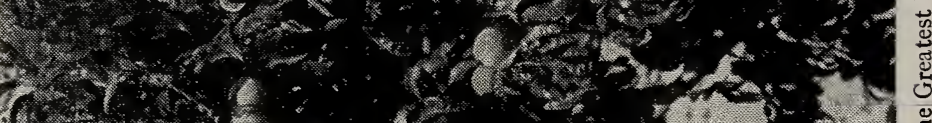

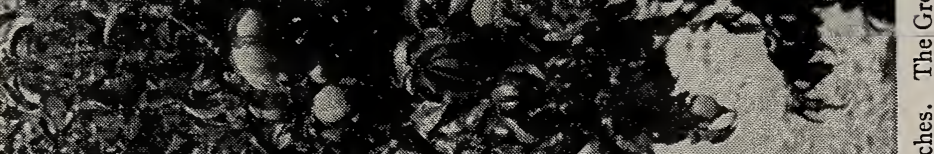

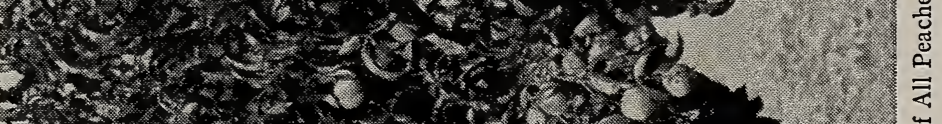

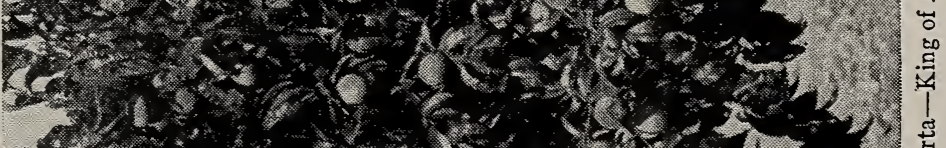

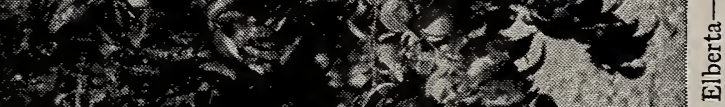

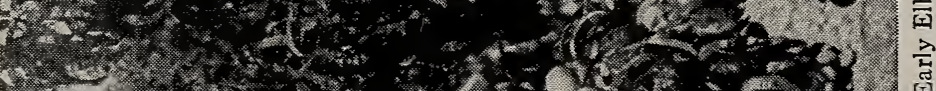

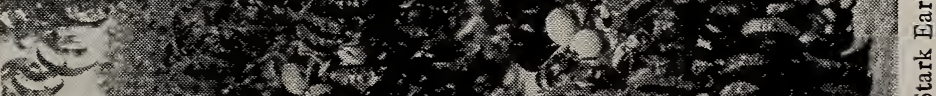

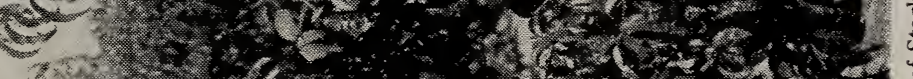

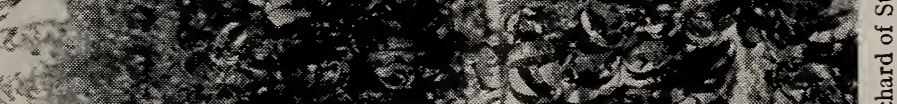

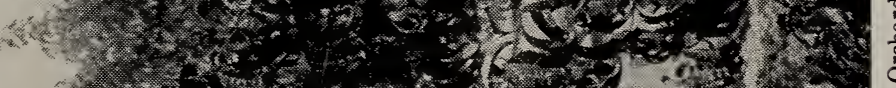

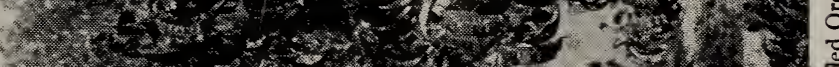

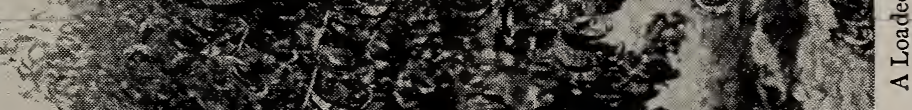

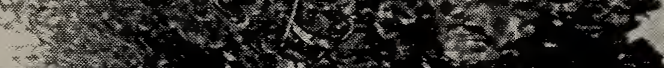

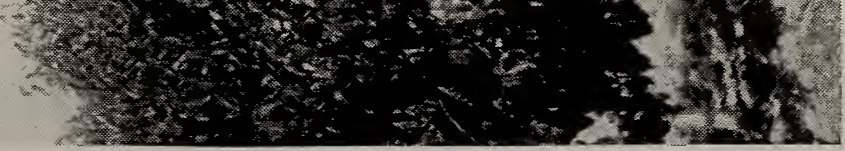




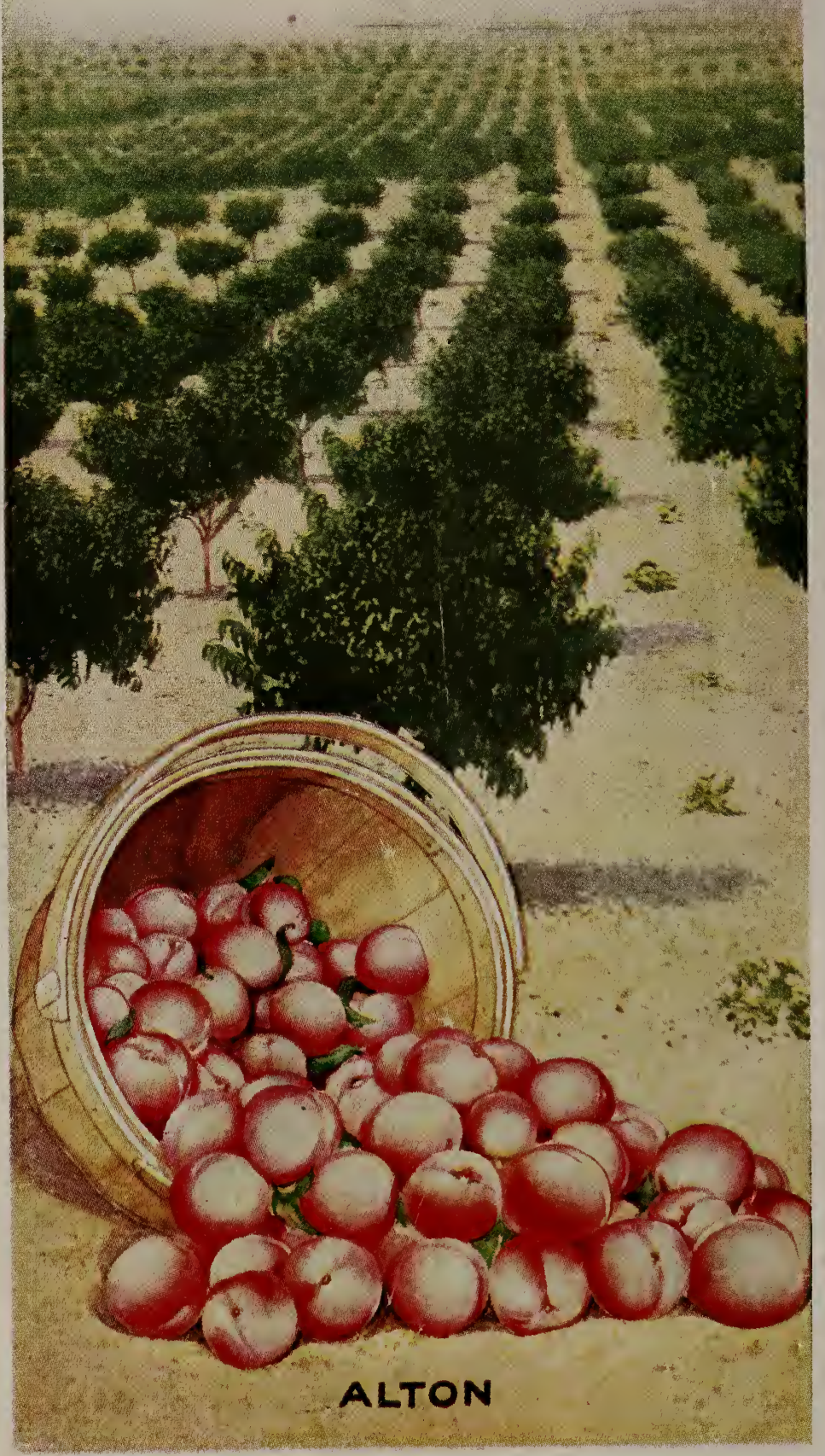

